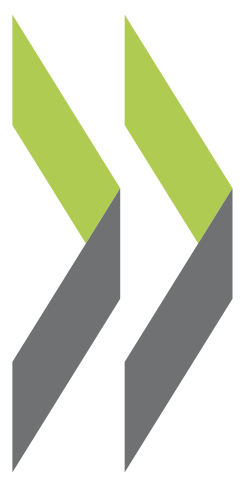

OECD Economics Department Working Papers No. 1395

Fighting gender inequality Christophe André, in Sweden Hugo Bourrousse 


\section{Unclassified}

ECO/WKP(2017)27

Organisation de Coopération et de Développement Économiques

Organisation for Economic Co-operation and Development

20-Jun-2017

ECONOMICS DEPARTMENT

English - Or. English

FIGHTING GENDER INEQUALITY IN SWEDEN

ECONOMICS DEPARTMENT WORKING PAPERS No. 1395

By Christophe André and Hugo Bourrousse

OECD Working Papers should not be reported as representing the official views of the OECD or of its member countries. The opinions expressed and arguments employed are those of the author(s).

Authorised for publication by Alvaro Pereira, Director, Country Studies Branch, Economics Department.

All Economics Department Working Papers are available at www.oecd.org/eco/workingpapers

JT03416482

Complete document available on OLIS in its original format

This document, as well as any data and map included herein, are without prejudice to the status of or sovereignty over any territory, to the delimitation of international frontiers and boundaries and to the name of any territory, city or area. 
OECD Working Papers should not be reported as representing the official views of the OECD or of its member countries. The opinions expressed and arguments employed are those of the author(s).

Working Papers describe preliminary results or research in progress by the author(s) and are published to stimulate discussion on a broad range of issues on which the OECD works.

Comments on Working Papers are welcomed, and may be sent to OECD Economics Department, 2 Rue André-Pascal, 75775 Paris Cedex 16, France, or by e-mail to eco.contact@oecd.org.

All Economics Department Working Papers are available at www.oecd.org/eco/workingpapers.

This document and any map included herein are without prejudice to the status of or sovereignty over any territory, to the delimitation of international frontiers and boundaries and to the name of any territory, city or area.

The statistical data for Israel are supplied by and under the responsibility of the relevant Israeli authorities. The use of such data by the OECD is without prejudice to the status of the Golan Heights, East Jerusalem and Israeli settlements in the West Bank under the terms of international law.

Latvia was not an OECD Member at the time of preparation of this publication. Accordingly, Latvia does not appear in the list of OECD Members and is not included in the zone aggregates.

\section{(C) OECD (2017)}

You can copy, download or print OECD content for your own use, and you can include excerpts from OECD publications, databases and multimedia products in your own documents, presentations, blogs, websites and teaching materials, provided that suitable acknowledgment of OECD as source and copyright owner is given. All requests for commercial use and translation rights should be submitted to rights@oecd.org 


\section{ABSTRACT/RESUME}

\section{Fighting gender inequality in Sweden}

Sweden ranks among the best OECD countries in terms of gender equality. Women have a high employment rate, outperform men in education and are well represented in government and parliament. Nevertheless, without further policy measures, achieving parity is still a distant prospect in several areas. Wage differences between genders persist; women are under-represented on private company boards, in senior management positions, in many well-paid and influential professions and among entrepreneurs. Hence, there is scope to make further progress on gender equality. The share of the parental leave reserved for each parent should be increased further, as inequality in leave-taking and long parental leaves harm women's career prospects. Fighting stereotypes in education is necessary to improve women's access to professions where they are under-represented. Government programmes need to promote women's entrepreneurship further. Special attention should also be paid to the integration of foreign-born women, whose employment rate is much lower than for their male counterparts.

This Working Paper relates to the 2017 OECD Economic Survey of Sweden (www.oecd.org/eco/surveys/economic-survey-sweden.htm).

Keywords: Corporate governance, Discrimination, Economics of Gender, Education, Gender equality, Immigration, Parental leave, Public policy, Sociology of Economics, Welfare Economics

JEL: A14, D63, G30, I24, J15, J16, J78

$* * * * * * * * * * * * * *$

\section{Lutter contre les inégalités hommes-femmes en Suède}

La Suède figure parmi les meilleurs pays de l'OCDE en termes d'égalité hommes-femmes. Les femmes ont un taux d'emploi élevé, un niveau d'éducation supérieur à celui des hommes et sont bien représentées au sein du gouvernement et du parlement. Néanmoins, en l'absence de nouvelles mesures politiques, la réalisation de la parité est encore une perspective lointaine dans plusieurs domaines. Les différences de salaire entre hommes et femmes persistent; Les femmes sont sous-représentées dans les conseils d'administration des entreprises privées, dans les postes de direction, dans de nombreuses professions bien rémunérées et influentes et parmi les entrepreneurs. Par conséquent, il existe des possibilités de progrès supplémentaires sur l'égalité hommes-femmes. La part du congé parental réservée à chaque parent devrait être encore augmentée, car les inégalités dans les congés pris et les longues absences parentales nuisent aux perspectives de carrière des femmes. La lutte contre les stéréotypes dans l'éducation est nécessaire pour améliorer l'accès des femmes aux professions dans lesquelles elles sont sousreprésentées. Les programmes gouvernementaux doivent promouvoir davantage l'entreprenariat féminin. Une attention particulière devrait également être accordée à l'intégration des femmes nées à l'étranger, dont le taux d'emploi est nettement inférieur à celui de leurs homologues masculins.

Ce Document de travail se rapporte à l'Étude économique de l'OCDE de la Suède, 2017

(www.oecd.org/fr/eco/etudes/etude-economique-suede.htm).

Mots-clés: Gouvernance d'entreprise, Discrimination, Économie de l'égalité hommes-femmes, Éducation, Égalité hommes-femmes, Immigration, Congé parental, Politique publique, Sociologie de l'économie, Économie du bien-être

JEL: A14, D63, G30, I24, J15, J16, J78 


\section{TABLE OF CONTENTS}

Reducing gender inequality lifts economic performance and well-being .............................................6

Enhancing labour participation and opportunities increases potential output .....................................6

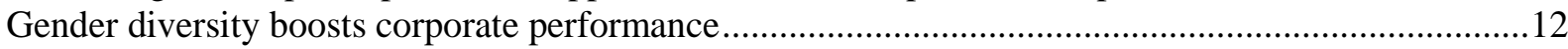

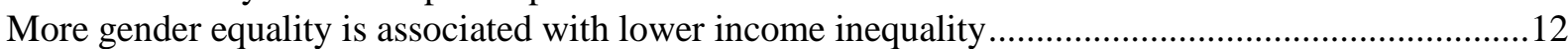

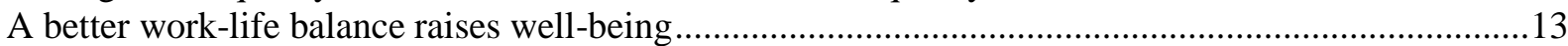

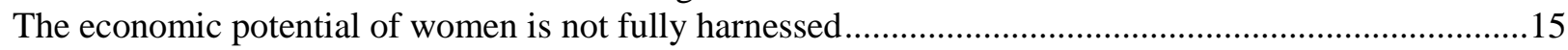

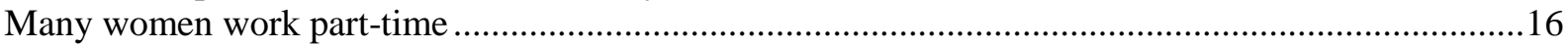

Women take on a larger share of unpaid work ................................................................................17

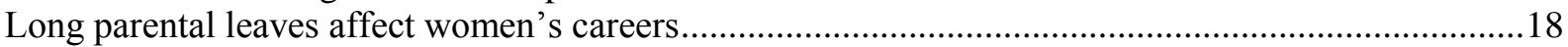

The gender pay gap persists, even though it is shrinking .................................................................19

Despite success in political representation, the glass ceiling remains in many other areas ...................21

Segregation and stereotypes in education and the labour market need to be fought ..............................23

Female entrepreneurship should be promoted further ........................................................................24

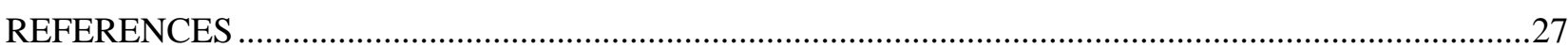

\section{Tables}

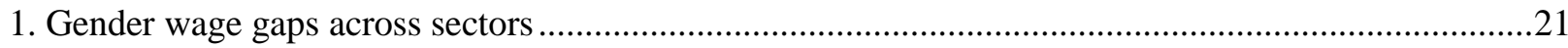

\section{Figures}

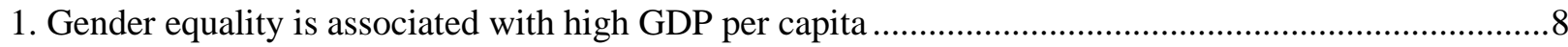

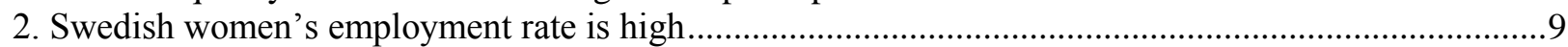

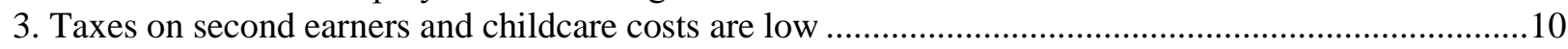

4. Foreign-born women's employment rate is low compared to natives .................................................11

5. Gender equality is associated with low income inequality ................................................................13

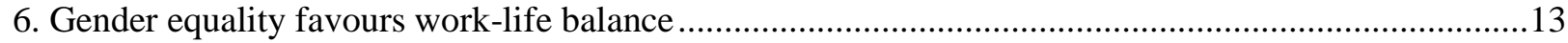

7. Women score higher than men on many well-being dimensions …..................................................15

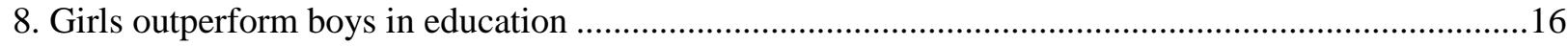

9. Many women work part time, often involuntarily ...........................................................................

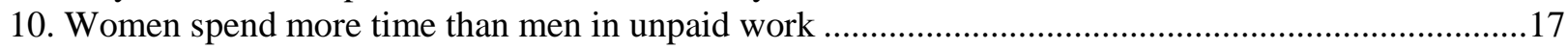

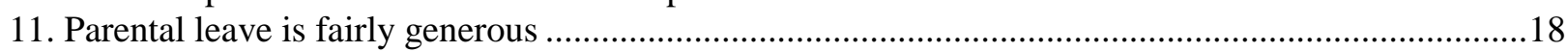

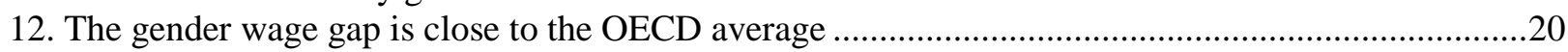

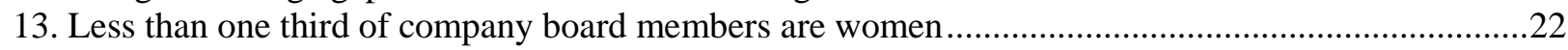

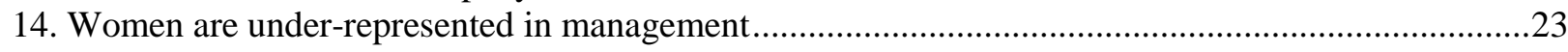

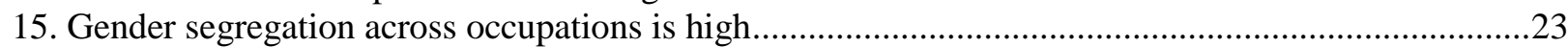

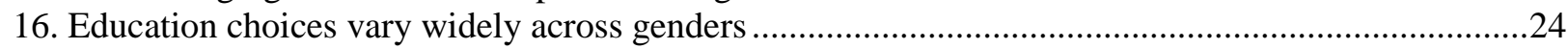

17. Only a third of sole-proprietor enterprises are owned by women .....................................................25

\section{Boxes}

Box 1. Sweden is a leader in gender equality 


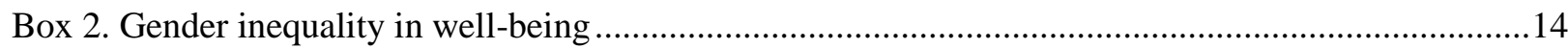

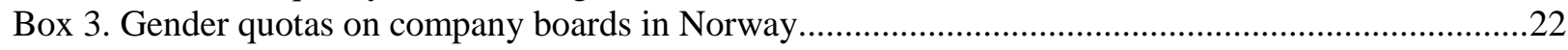

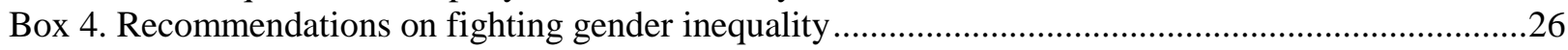




\title{
Fighting Gender Inequality in Sweden
}

\author{
By Christophe André and Hugo Bourrousse ${ }^{l}$
}

Gender inequality in Sweden is low by OECD standards, largely thanks to policies which have been promoting equality for decades, including childcare and parental leave policies, individual taxation and mainstreaming gender issues. Sweden, along with the other Nordic countries, is among the best performers in international gender equality rankings (Box 1). Nevertheless, gender equality in economic participation has not been achieved yet, implying a sub-optimal use of a highly qualified workforce that holds back potential growth. Recruitment and promotion practices, occupational choices and a gender pay gap, albeit a shrinking one, contribute to income and wealth inequality. They also reduce well-being, both for women and men, in particular by affecting the balance between work, family commitments and personal life. The government has recently extended the share of parental leave reserved for each parent. Fighting stereotypes early in education is also needed to reach a better gender balance in occupations associated with high social status and pay, where women are often under-represented. Further promoting female entrepreneurship, which is growing fast from a relatively low level, would contribute to both gender equality and economic dynamism. Gender policy should also pay attention to weak men's outcomes in some areas, including under-representation in some traditionally female-dominated professions where job opportunities are growing (e.g. education, social services) and under-achievement in education.

\section{Reducing gender inequality lifts economic performance and well-being}

In addition to ethical arguments for lowering gender inequality there is also ample evidence that lower gender inequality is associated with stronger economic performance and lower income and wealth inequality. Fairer opportunities tend to raise the participation of women in the labour market, and hence to increase labour supply, but also to improve the matching between women's skills and jobs, which lifts productivity. Higher labour participation tends to reduce income inequality, reflecting large income differences between people in- and out of work. Greater diversity in the workplace is also bound to favour innovation, through enhanced information and analysis capabilities.

\section{Enhancing labour participation and opportunities increases potential output}

Countries where gender inequality is low tend to enjoy higher incomes and higher standards of living. Gender equality, as measured by the World Economic Forum's Global Gender Gap index, is positively correlated with the level of GDP per capita across OECD countries (Figure 2.1). Gonzales et al. (2015) find a negative relationship between the United Nations Gender Inequality Index and both GDP per capita and GDP growth in a sample covering advanced, emerging and low-income countries. A positive relationship between the European Institute for Gender Equality index and GDP per capita is also found across EU-28 countries (European Institute for Gender Equality, 2015).

\footnotetext{
${ }^{1}$ Christophe André is from the OECD Economics Department. Hugo Bourrousse was at the OECD Economics Department at the time of writing. The authors would like to thank Mark Baker, Robert Ford, Åsa Johansson, Vincent Koen, Patrick Lenain, Jon Kristian Pareliussen and Alvaro Pereira from the OECD Economics Department, Willem Adema and Angelica Salvi Del Pero from the OECD directorate for Employment, Labour and Social Affairs, Anna Milanez from the OECD Centre for Tax Policy and Administration, as well as members of the Swedish administration and the OECD Economic Development Review Committee for valuable comments and suggestions. Mercedes Burgos and Sisse Nielsen (also from the OECD Economics Department) provided excellent secretarial support.
} 


\section{Box 1. Sweden is a leader in gender equality}

Sweden is among the top performers in the main international gender equality rankings. It comes first in the Gender Equality Index 2015 from the European Institute for Gender Equality, a composite index based on 2012 gender gaps and levels of achievement in the key policy areas relevant to gender equality (European Institute for Gender Equality, 2015). The gap to the average of the other EU-28 members has remained roughly constant since the 2005 introduction of the index. Sweden's score indicates that about three-fourths of the way towards a gender-equal and cohesive society has been covered, compared to about half for the EU-28 average and less than $40 \%$ for the lowest performing OECD country that is a member of the EU (Italy). Looking at sub-indices, Sweden tops the ranking for work (participation and quality), comes second to Denmark for knowledge (attainment, segregation and lifelong learning), second to Finland for power (political and economic), third behind Luxembourg and the Netherlands for money (level and distribution of income and risk of poverty), third behind Denmark and the Netherlands for time (time spent in care and social activities) and seventh in health (status and access to care). A weak spot is the low gender equality index score for employment of foreign-born relative to natives, although this has to be seen in the light of the strong employment rate of Swedish women.

Sweden ranks fourth in the 2016 World Economic Forum's Global Gender Gap index for the seventh consecutive year, behind Iceland, Norway and Finland (World Economic Forum, 2016). The overall performance is driven by high scores in economic participation and opportunity, where Sweden ranks fourth and political empowerment, where it ranks fifth, despite being the only Nordic country which has had no female head of government in the past 50 years.

Sweden ranks sixth on the 2015 United Nations Development Programme (UNDP) gender equality indicator, which covers empowerment, labour market and reproductive health, scoring high in all categories (United Nations Development Programme, 2015).

Causality between higher gender equality and higher incomes runs in both directions (Duflo, 2012). High incomes and standards of living entail more opportunities for women, including better access to health and education, which is key to empowering women. Higher levels of economic development are also generally associated with more economic and political rights and opportunities for individuals and especially for women. Gender equality contributes to higher economic well-being primarily through reducing gaps in education, health, and labour participation and through better career opportunities for women.

Gaps in education and health are considerable obstacles to economic growth particularly in lowincome countries (Gonzales et al., 2015). In OECD countries, there is also evidence that the reduction in the gender gap in education has had a positive and significant impact on GDP per capita growth over the period 1960-2008 (Thévenon and Salvi Del Pero, 2015). Success in reducing these gaps over time has led to the near-elimination of education and health gaps in most advanced economies. In Sweden, educational attainment is higher for women than for men (Salvi del Pero and Bytchkova, 2013). Upper secondary graduation rates for women and men were respectively $73 \%$ and $65 \%$ in 2014 and more than half of women aged 25-34 have a tertiary degree, compared to only about $40 \%$ of men in the same age group (OECD, 2016a). However, women are under-represented among engineering and computing graduates. As in other advanced economies, the impact of gender inequality on economic growth is mainly related to gaps in labour participation and weaker career opportunities for women. 
Figure 1. Gender equality is associated with high GDP per capita

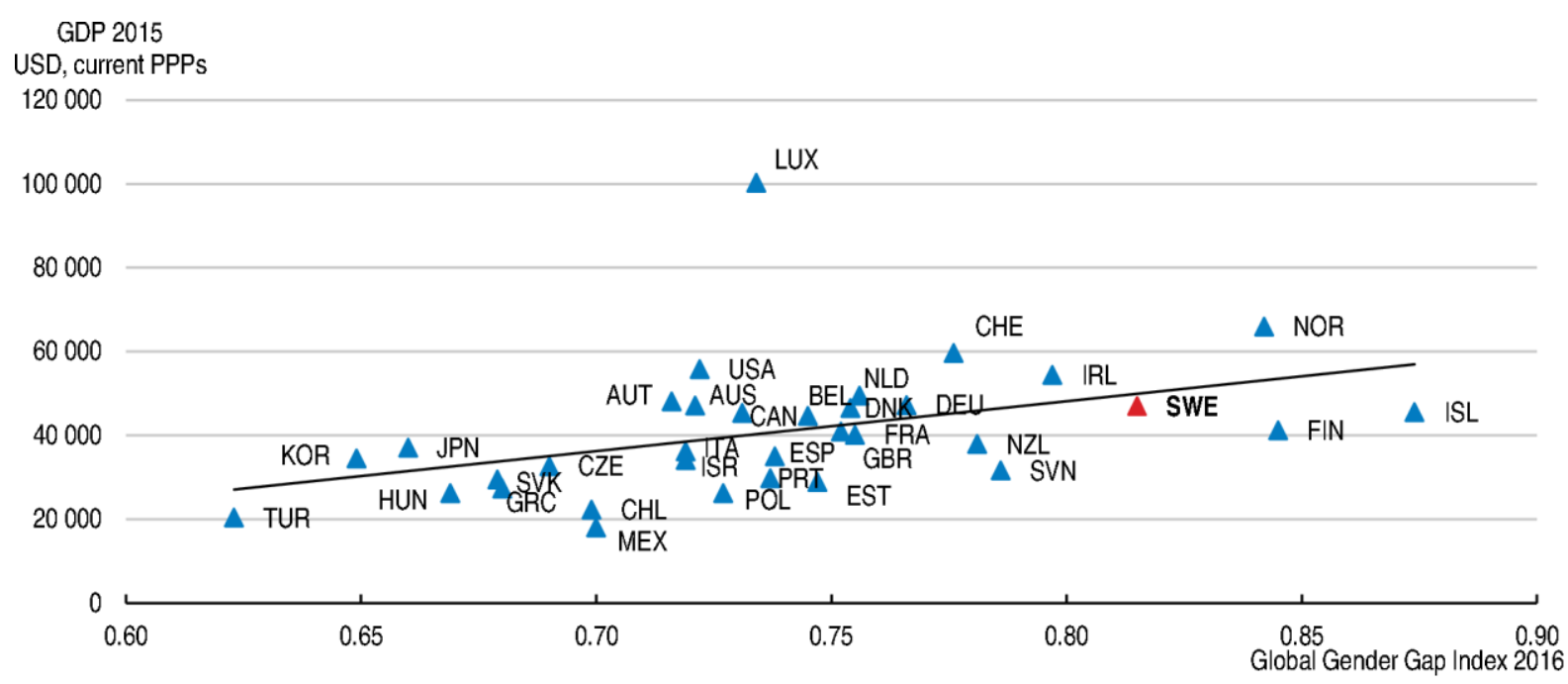

Source: World Economic Forum and OECD Productivity Database.

Sweden has the third highest female employment rate in the OECD, behind Iceland and Switzerland (Figure 2, Panel A). The gender gap in employment rates is the second lowest behind Finland (Figure 2, Panel B). In interaction with societal values, policies have played a major role in promoting the integration of women in the labour market. The rapid expansion of the public sector in the 1960s and 1970s also increased women's employment opportunities. Beside general policies like universal access to education and health care, which were put in place early in Sweden and tend to benefit women disproportionately in the early stages of implementation, specific policies have provided incentives and support for women to enter the labour market. The taxation of second earners is highly relevant when considering the incentives of women to seek employment, as second earners tend to be women, with $62 \%$ of couples with dependent children having female second earners in 2011 (Rastrigina and Verashchagina, 2015). Sweden has relatively low taxation of second earners due to income taxation at the individual rather than at the household level since 1971 (Gunnarsson, 2016). Individual taxation results in second earners facing one of the lowest income tax burdens amongst OECD countries, which provides a powerful incentive for women to seek employment (Figure 3, Panel A). Similarly, social security legislation is based on individual insurance.

Access to affordable childcare also favours female employment. Sweden is among the few EU countries that meet both targets on formal childcare provision set at the 2002 European Council in Barcelona: ensuring suitable childcare provision for at least $33 \%$ of children under three years of age and for at least $90 \%$ of children between three and the mandatory school age (European Institute for Gender Equality, 2015). The net cost of childcare is among the lowest in the OECD (Figure 3, Panel B).

Increased female labour force participation would lift Swedish growth. Simulations based on OECD long-term growth scenarios suggest that halving the gender gap in participation by 2030 would raise the level of Swedish GDP by $2.3 \%$. Fully closing the gap would raise GDP by $4.6 \%$ (OECD, 2012). These potential gains are substantial, though smaller than in many other OECD countries, notably in Southern and Eastern Europe and Latin America, where gender participation gaps are much wider. Progress can also be made in limiting the high share of Swedish women who work part-time involuntarily, who currently account for $11 \%$ of total female employment (see below). While closing the gender participation gap would increase the labour force by $3.4 \%$ in 2030 , convergence in full-time equivalent terms would lift labour input by close to $10 \%$. 
Figure 2. Swedish women's employment rate is high
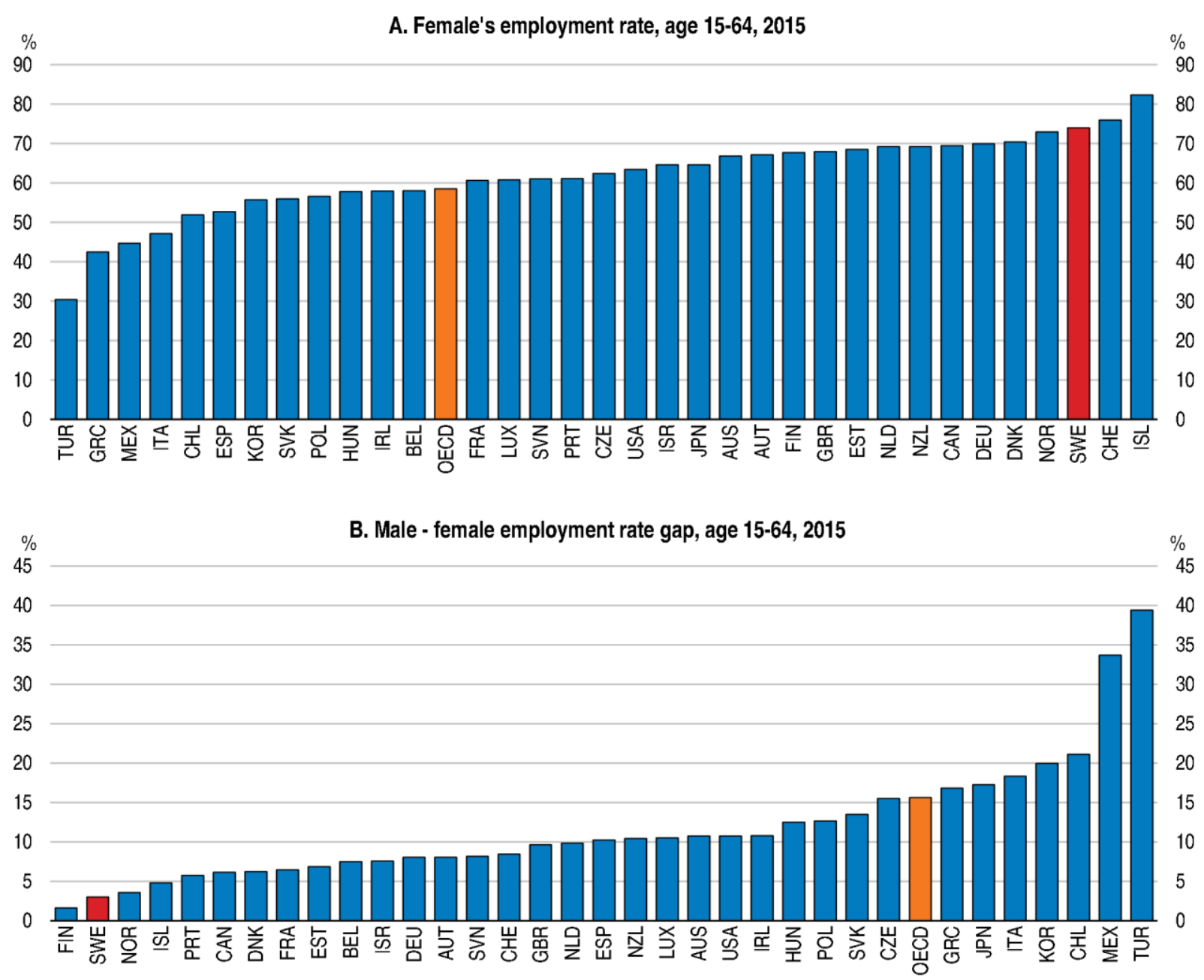

Source: OECD Labour Force Statistics.

A particular challenge for Sweden, given the large inflows of migrants, will be to encourage labour participation and employment opportunities of foreign-born women. Sweden has the widest gap in employment rates between native and foreign-born individuals among OECD countries (Figure 4). This is largely explained by the composition of immigration to Sweden, which includes a large share of refugees and family-reunion immigrants with relatively low skills, while low-skilled jobs account for only about 5\% of total employment. Furthermore, the gap in employment between natives and foreign-born is much larger for women (18 percentage points) than for men (11 percentage points). Women aged 20-64 with belowsecondary education and born in Asia or Africa had an employment rate as low as 33\% in 2015, even though their participation rate was above 50\% (Swedish Fiscal Policy Council, 2016).

In addition, migrant women tend to drop out of the labour force following the completion of the government-mandated integration programme. The two-year introduction programme provides a wide range of targeted activities aimed at preparing new humanitarian migrants and their families to enter the labour market. One year after completing the programme, nearly one in five women is neither employed, nor in training or education (NEET), or even registered with the public employment service. The NEET rate is particularly high, at nearly $27 \%$, for women who arrived after the age of 15 . It compares with a rate of about $16 \%$ for their male counterparts and a rate of around $11 \%$ for native-born women with two nativeborn parents. 
Figure 3. Taxes on second earners and childcare costs are low 2012
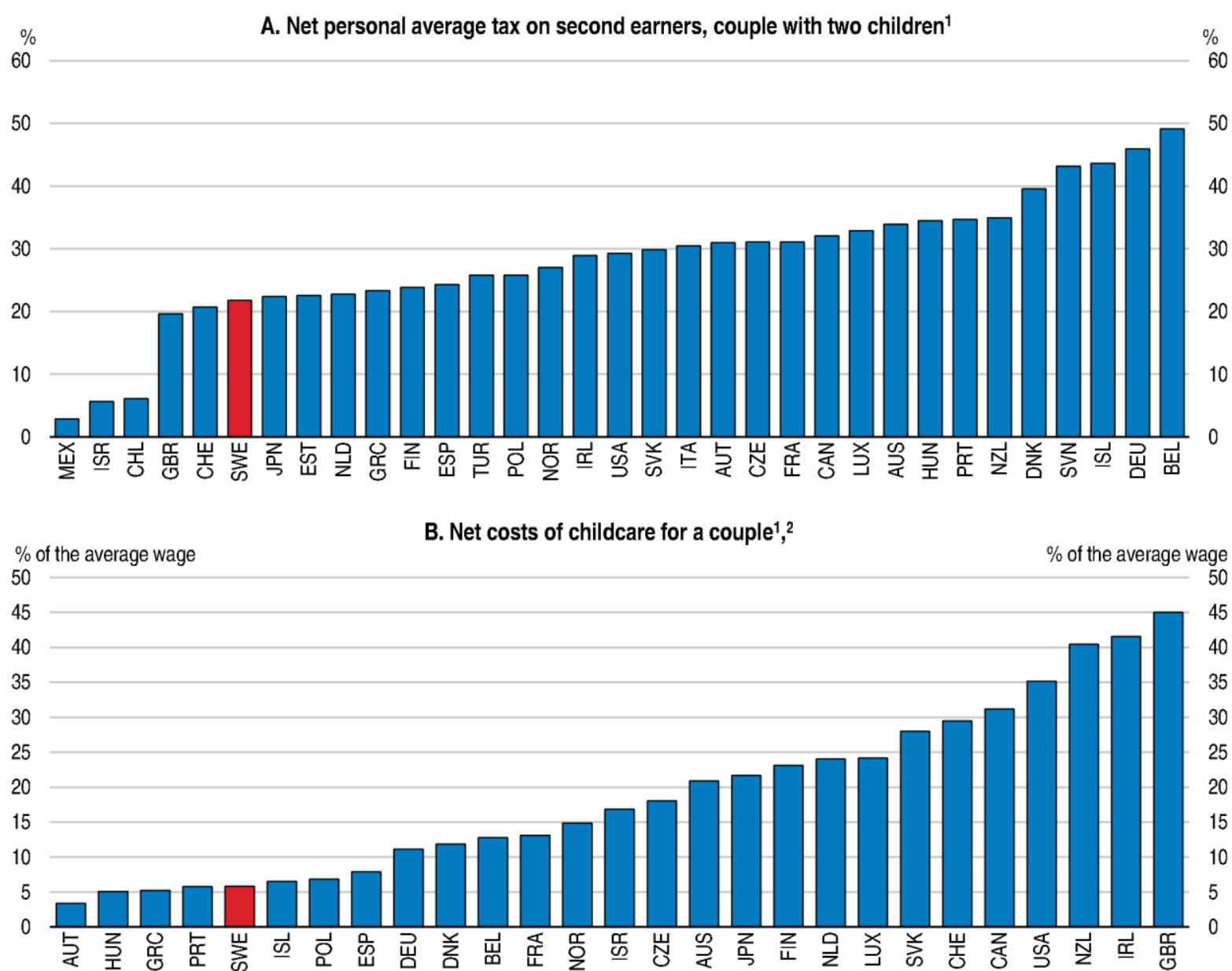

1. The first earner earns $100 \%$ of the average wage and the second $67 \%$.

2. For children aged 2 and 3 . In a number of countries, available fee information relates to a particular region or municipality: Austria (Vienna), Belgium (Wallonia), Canada (Ontario), Finland (Helsinki), Germany (Hamburg), Iceland (Reykjavík), Japan (Tokyo), Poland (Warsaw), Switzerland (Zürich), United Kingdom (England) and the United States (Michigan).

Source: OECD Taxing Wages 2016, OECD Tax-Benefit Models.

This calls for better follow-up and support to help foreign-born women to further integrate and remain in the labour market. Measures recently taken by the government to support the integration of migrants, such as reforming Swedish Tuition for Immigrants (SFI), enhancing validation of qualifications and further investments in adult and vocational education, will help both men and women. However, additional measures targeted at female labour market participation are warranted given the greater difficulties they face in entering and remaining in the workforce. In July 2016, the government announced a new programme to tackle segregation, including a requirement for the public employment service to focus on measures to increase employment among foreign-born women (Swedish Government, 2016a). Policies should continue to reach out to foreign-born women in a systematic way when the Introduction programme ends, to prevent them from drifting away from the labour market. Evidence from Australia, Denmark and Norway suggests that mentoring schemes and programmes targeted at women with a refugee background can play an important role in supporting foreign-born women's access to jobs, as well as bringing additional benefits to society. In particular, diversifying the workforce in sectors like health and education can make it more responsive to the needs of families from various backgrounds, which in turn helps the integration of immigrants. This is all the more relevant as Sweden is facing labour shortages in these areas, which properly trained immigrants could help reduce (OECD, 2016b). 
Figure 4. The foreign-born female employment rate is low compared to natives ${ }^{1}$

2015
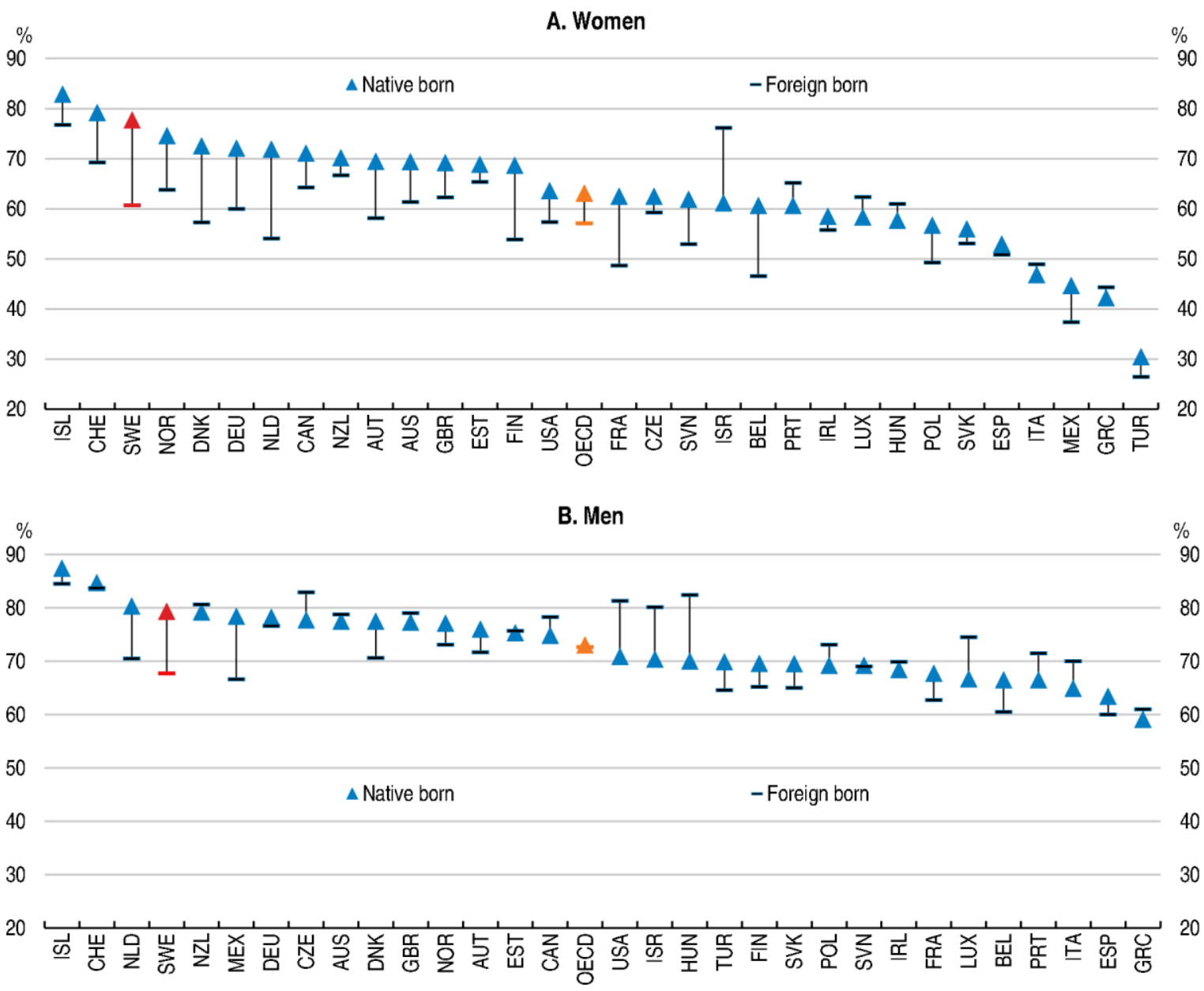

1. OECD averages exclude Chile, Japan, Korea, and Latvia.

Source: OECD Migration Statistics.

The magnitude of the impact of higher female employment on output depends on the productivity of the newly employed. These individuals may have lower education, less skills and experience, may have been out of work for a long time and may work in low-productivity sectors. Their inclusion in the labour market could therefore put downward pressure or even subtract from aggregate productivity growth, especially in the short term. Although such a trade-off is indeed evident across OECD countries the negative impact is relatively weak. Boulhol and Turner (2009) find that across OECD countries a $1 \%$ gain in employment is associated with a decrease of $0.24 \%$ in labour productivity. McGuckin and van Ark (2005) find that a $1 \%$ increase in employment lowers labour productivity by $0.3 \%$ in a sample covering the OECD and a few additional European countries. Moreover, the impact of participation on productivity is relatively short-lived, disappearing in less than five years. While increased female participation has been associated with lower productivity growth in the past, this is linked to specific age and cohort effects and is likely to fade away over time. This is especially true in Sweden, where women have higher levels of education attainment than men.

The impact of workers previously employed part-time and foreign-born women could drag productivity down through the direct effect associated with the factors listed above and also through increased skill mismatch, which has been associated with lower productivity across OECD countries (Adalet McGowan and Andrews, 2015a). While the incidence of skill mismatch in Sweden is among the 
lowest in the OECD, specific groups may face a higher risk. On average in OECD countries, women are less likely to experience skill mismatch than men. However, the probability of mismatch is higher for immigrants and part-time workers, although there is no evidence of an impact of the latter on matching in Sweden (Adalet McGowan and Andrews, 2015b). Policy-related factors may have opposite effects on matching in Sweden. On the one hand, product market regulations are relatively lean and participation in lifelong learning is high, which should facilitate matching. On the other hand, employment protection legislation is high for permanent contracts and flexibility in entry level wages is limited (2015 OECD Economic Survey of Sweden). The structural shortage of housing in the big cities and the very strict rental market regulations are obstacles to residential mobility and are likely to reduce the efficiency of labour allocation (Adalet McGowan, 2013).

\section{Gender diversity boosts corporate performance}

There is growing evidence that firms with greater gender diversity tend to be more innovative and profitable. Catalyst (2011) shows that Fortune 500 companies with at least three women board directors significantly outperform companies with only male board directors. The female inclusive boards outperformed in terms of return on sales $(+84 \%)$, return on invested capital $(+60 \%)$ and return on equity $(+46 \%)$. Curtis et al. (2012) find that the relative share price performance of firms with at least one woman on their board is $26 \%$ higher for large-cap companies and $17 \%$ for smaller and mid-cap enterprises. Shares in companies with women on their board started to outperform others after the 2008 global financial crisis, suggesting that gender diversity on boards is associated with reduced volatility in stock returns possibly reflecting the tendency for female directors to be more risk averse than male directors (Croson and Gneezy, 2009; OECD, 2015a). Similarly, gender diversity is found to have a positive impact on the quality of credit and the profitability of Italian banks, which may be linked to women's higher risk aversion and greater attention to monitoring activities (Del Prete and Stefani, 2015). Hunt et al. (2015) find in a sample of 366 companies from Canada, Latin America, the United Kingdom and the United States, that firms in the top quartile for gender equality were $15 \%$ more likely to have financial returns above their national industry median than those in the lower quartile. Noland et al. (2016) find in an analysis of 21980 companies from 91 countries, that the presence of women in corporate leadership may improve firm performance through returns from non-discrimination and increased skill diversity. The effect is sizeable: an increase in female leaders from zero to $30 \%$ is associated with a $15 \%$ increase in the net revenue margin.

There is evidence that greater diversity, in terms of gender but also other dimensions such as ethnicity or culture, can enhance firm performance. In a fast-moving business environment, more diverse groups are likely to be better at rapidly finding responses to problems and at spotting new opportunities. Woolley et al. (2010) find that collective intelligence, defined as the general ability to perform a wide variety of tasks, increases with the proportion of women in a group. Homogenous groups may suffer from narrowmindedness, groupthink - the tendency to agree with a group's consensus without critical thinking - and over-confidence, whereas diversity fosters creativity and innovation through enhanced information processing and complex thinking (Galinsky et al., 2015). In addition to improved group decision-making, gender diversity offers access to a larger pool of talent, a wider span of management skills, a better understanding of customer preferences, and improved corporate governance (Curtis et al., 2012). The correlation between gender diversity and economic performance does not necessarily imply that causality only runs from diversity to economic growth. For example, well-performing firms may be more likely to encourage gender diversity or better managed firms with good corporate governance could lead to higher performance and more diversity.

\section{More gender equality is associated with lower income inequality}

Across OECD countries, gender equality is negatively correlated with the Gini coefficient on disposable income (Figure 5). Similar to the relationship between gender equality and GDP, this 
correlation is observed in samples extending to non-OECD countries. Gender equality may reduce income inequality through several channels. The difference in labour participation is the main gender-related contributor to income inequality in advanced economies, while the gender pay gap has a direct, albeit smaller, effect on income inequality. Gender gaps in access to education and health, differences in political empowerment and unequal economic opportunities, which are important sources of income inequality in low-income and emerging economies, play a minor role in advanced economies (Gonzales et al., 2015).

Figure 5. Gender equality is associated with low income inequality

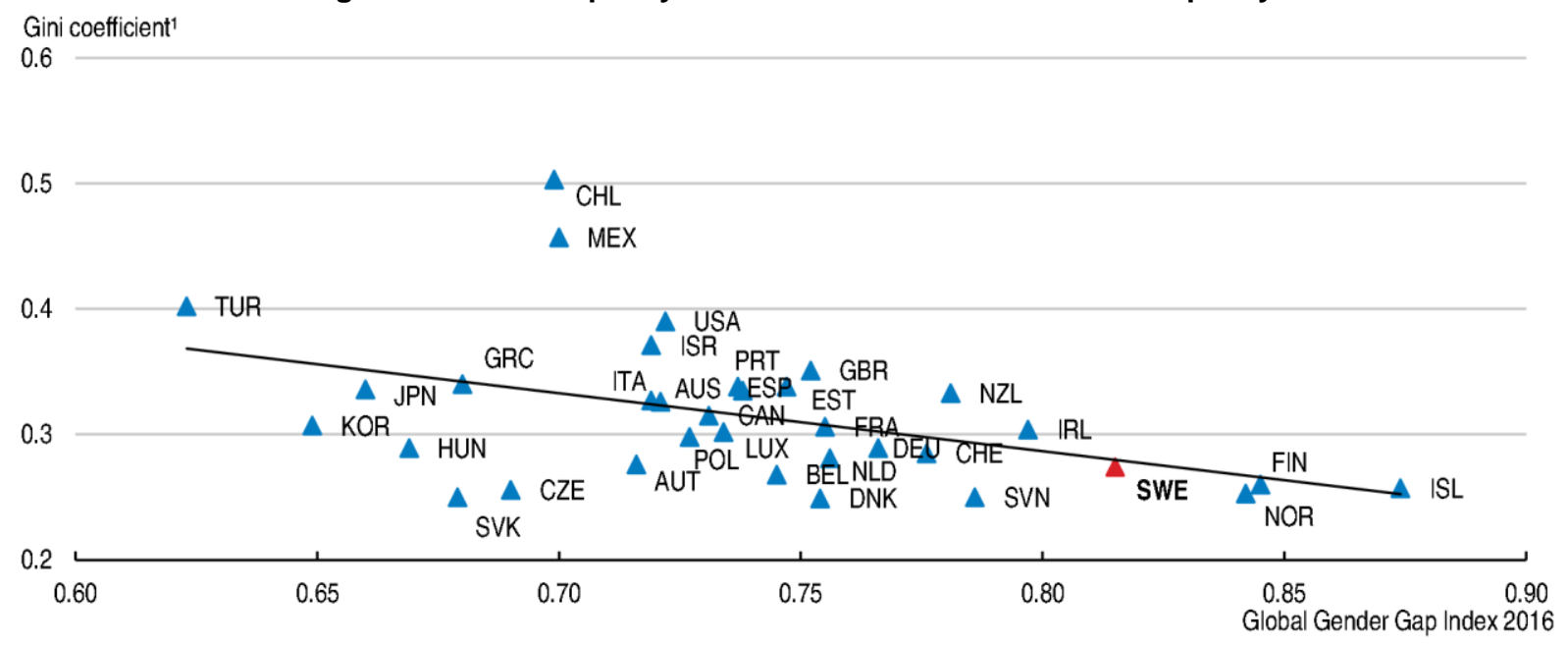

1. Gini coefficient on disposable income, latest data available.

Source: World Economic Forum, OECD Income Distribution Database.

\section{A better work-life balance raises well-being}

In addition to its contribution to economic performance, gender equality improves well-being, for both women and men. Allowing men and women to successfully combine work and family commitments is a major contributor to increased subjective well-being. The work-life balance component of the OECD's Better Life Index, covering both women and men, is strongly correlated with the WEF Global gender gap index across OECD countries (Figure 6). In Sweden, women fare better than men in five of the eight dimensions of the OECD's well-being index, which compares favourably to the OECD average (Box 2).

Figure 6. Gender equality favours work-life balance

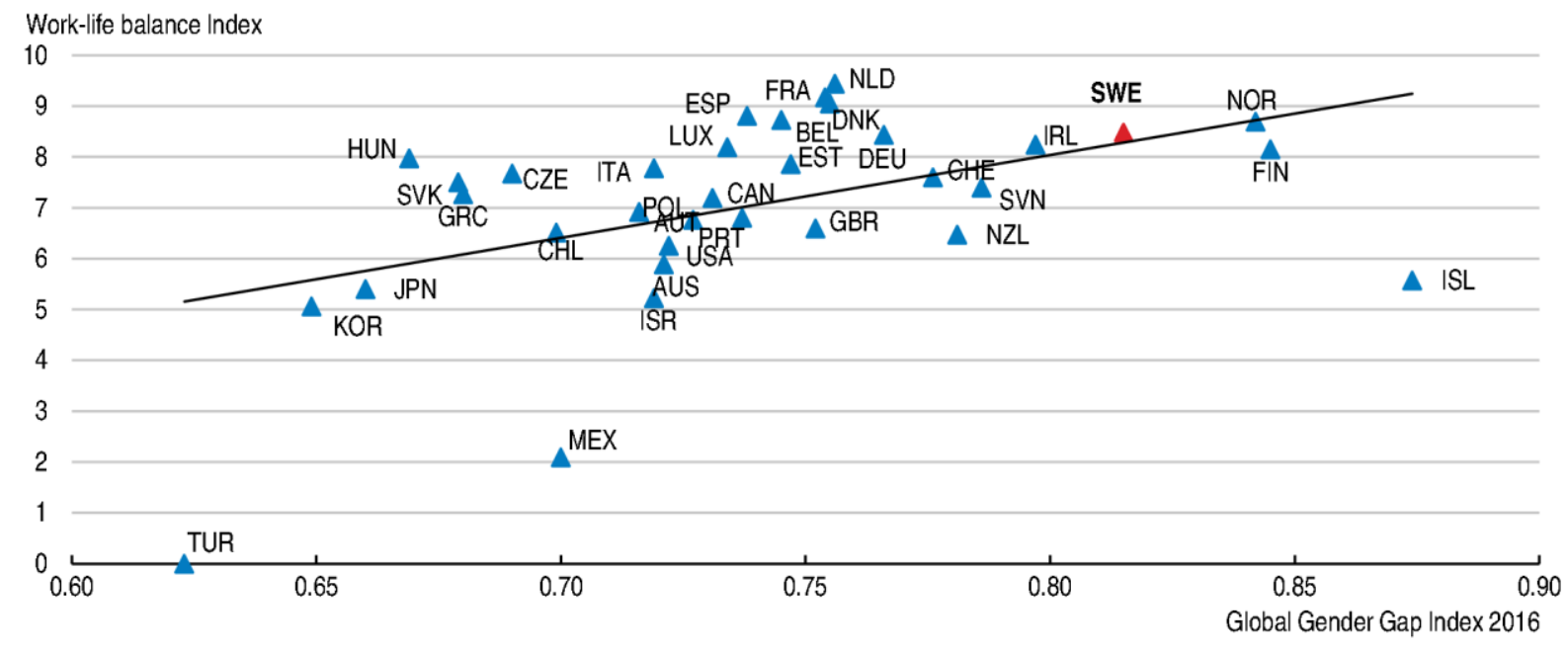

Source: World Economic Forum and OECD Better Life Index 2016. 


\section{Box 2. Gender inequality in well-being}

In Sweden, as in other Nordic countries, women appear to be slightly more satisfied than men with their lives. Furthermore, Sweden is one of the few OECD countries where women report a higher positive affect balance (a measure that captures the extent to which positive feelings exceed negative ones at a specific point in time), which certainly matters in how they evaluate their lives as a whole (OECD, 2013). The most prominent gender differences in Swedish well-being include:

- Women have higher civic engagement than men, but weaker social networks.

- Despite having a longer life expectancy, women tend to report worse health conditions than men. The health gender gap is wider in Sweden than in the OECD and other Nordic countries (Figure 2.7). In 2012, Swedish women were $40 \%$ more likely to report limitations in daily activities due to health problems than men (OECD, 2013).

- Women have a lower suicide rate than men (7.2 for 100000 against 15.8 for 100000 for men), although it is one of the highest rates among women across OECD countries.

- With respect to safety, gender equality is far from being achieved: women and men differ in their exposure to crime (men are more likely to be homicide victims, while women are the primary victims of domestic and intimate partner violence), and women are more fearful of crime. Sweden shows a wide gender gap in safety, contrary to other Nordic countries. Accordingly, one of the Swedish government's gender policy priorities is to stop men's violence against women.

- Similarly to many other OECD countries, where girls have consistently outperformed boys in school, Swedish girls outperform boys on educational attainment, skills and number of years in education.

Well-being dimensions and their components

\begin{tabular}{|c|c|}
\hline \multirow{4}{*}{ Job } & Labour market insecurity \\
\hline & Employment rate \\
\hline & Long-term unemployment rate \\
\hline & Personal earnings \\
\hline Community & Ouality of support network \\
\hline \multirow{3}{*}{ Education } & Educational attainment \\
\hline & Student skills \\
\hline & Years in education \\
\hline \multirow{2}{*}{ Civic engagement } & Stakeholder engagement for developing regulations \\
\hline & Voter turnout \\
\hline \multirow{2}{*}{ Health } & Life expectancy \\
\hline & Self-reported health \\
\hline Life satisfaction & Life satisfaction \\
\hline \multirow{2}{*}{ Safety } & Feeling safe walking alone at night \\
\hline & Homicide rate \\
\hline \multirow{2}{*}{ Work-life balance } & Employees working very long hours \\
\hline & Time devoted to leisure and personal care \\
\hline
\end{tabular}

Despite the outperformance of females in many dimensions of subjective well-being, inequalities persist when it comes to jobs and earnings. Women have a slight advantage as regards jobs in Sweden and the other Nordics, which stems from lower labour market insecurity and a lower long-term unemployment rate. As fewer women than men work very long hours and a substantial fraction of women work part-time, women tend to have a better work-life balance. But women are still paid less than men and encounter more difficulties to access managerial positions. Women are also 
exposed to higher poverty risk after retirement. Due to lower pension contributions over the course of their lives, as well as to longer lives, the incidence of poverty among retired women is much higher than among retired men. In 2015, nearly $24 \%$ of women aged 65 or over were at risk of poverty compared to less than $12 \%$ of men, using a threshold of $60 \%$ of median equivalised income after social transfers (Eurostat, EU-SILC). Recent government measures to reduce differences in taxation between earned and pension income will benefit women disproportionately and contribute to closing this gap (Swedish Government, 2016b). A parliamentary group on pensions is also investigating ways to improve gender equality among pensioners, through a review of basic protection for over 65 year-olds and easing transfers of premium pension rights (the funded part of public earnings-related pensions) between spouses and registered partners.

\section{Figure 7. Women score higher than men on many well-being dimensions}

Ratio of women to men in well-being dimensions ${ }^{1}$

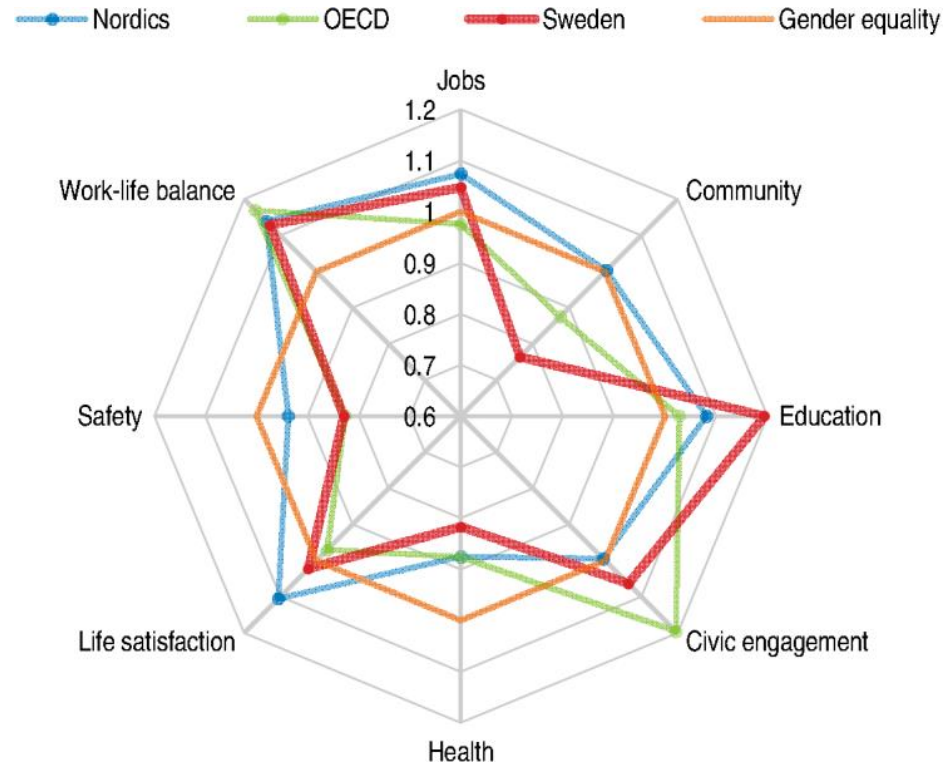

1. Each gender-specific well-being dimension has been calculated separately for men and women. Dimensions are measured by indicators from the OECD Better-Life Index, which are normalised to range between 0 and 1 and averaged within each dimension. The chart displays the ratio of women to men scores for each dimension. A value of 1 indicates gender equality; a value greater than 1 indicates that the well-being indicator is higher for women and conversely.

Source: OECD Better-Life Index 2016.

\section{The economic potential of women is not fully harnessed}

The female employment rate in Sweden is one of the highest in the OECD. However, many women work part-time, with many wanting to work more hours. Women also take on a disproportionate share of unpaid work. Furthermore, women are under-represented on private company boards, in senior management positions, in many well-paid and influential professions and among entrepreneurs. This situation endures despite the fact that Swedish women are highly skilled with more than half of women aged 25-34 holding a tertiary degree, compared to about $40 \%$ of men (Figure 8 ). Hence, there is potential to better harness the economic potential offered by women.

In order to promote gender equality, Parliament has decided on an overall objective stating that women and men are to have the same power to shape society and their own lives. Accordingly, the government has set out four intermediate objectives in its gender equality policy, three of which have a direct impact on the economic contribution of women: equal division of power and influence; economic equality; and equal distribution of unpaid housework and provision of care. The fourth objective is stopping men's violence against women (MHSA, 2015). Furthermore, the Government has recently 
established a gender equality agency, to reduce fragmentation and enhance implementation effectiveness of gender equality policies. The annual government budget contains a supplement with data and analyses on gender inequality which is a valuable tool for monitoring policy action and Sweden is among the OECD frontrunners in terms of gender budgeting (Quinn, 2016). However, the document could present data more consistently over time, which would allow a better monitoring of trends. Disaggregated gender data and analyses could be expanded in a number of key areas, including the impact of gender norms on economic choices, differences in employment and wages between natives and foreign-born, learning choices and returns to education, the glass ceiling, and financial and housing wealth. Additionally, more effort should be put into translating gender policy goals into intermediate targets on measurable outcomes, against which the impact of policies can be assessed (Swedish Fiscal Policy Council, 2016).

Figure 8. Girls outperform boys in education

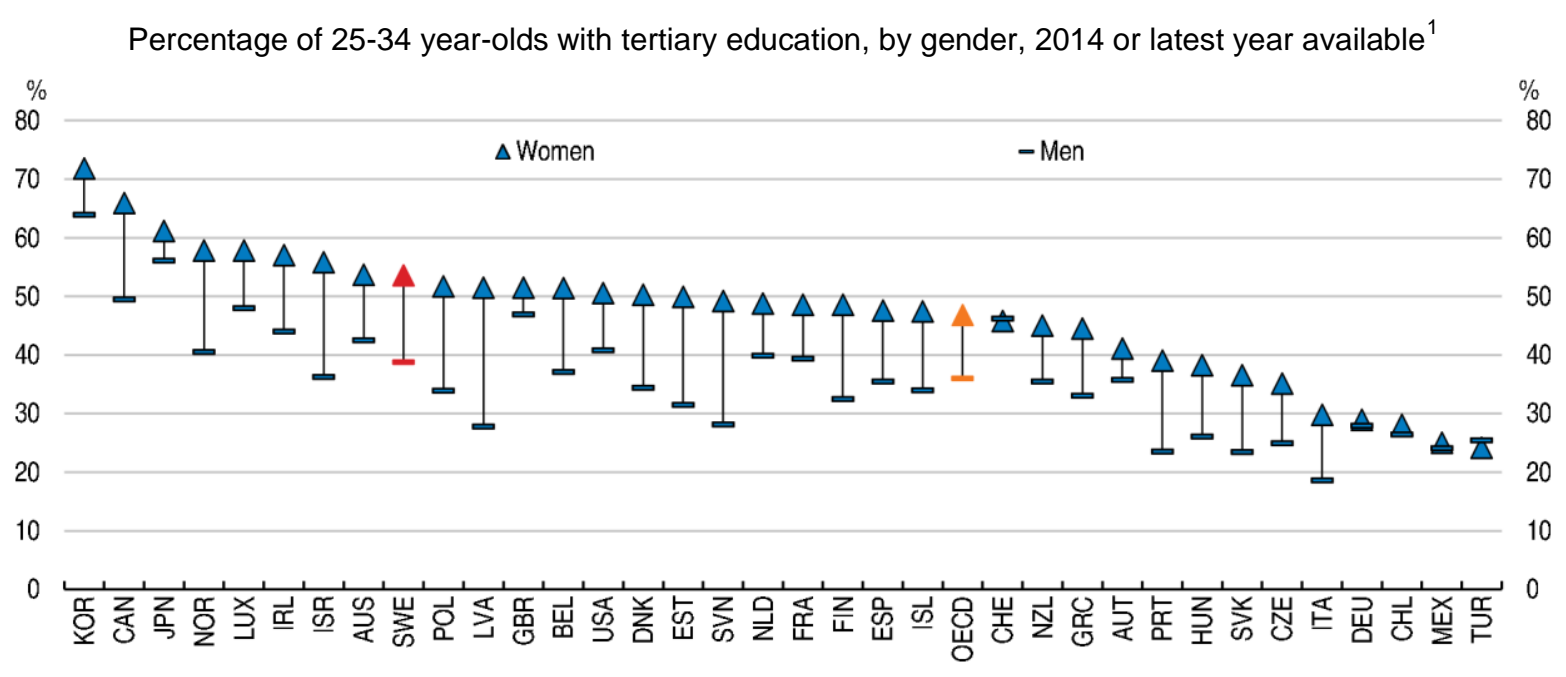

1. Unweighted average for the OECD.

Source: OECD Education at a Glance 2016.

\section{Many women work part-time}

Female employment is high, with around one woman in five working part-time, a level well below the OECD average (Figure 9, Panel A). However, around 60\% of women working part-time would like to work longer hours (Panel B). This is partly related to the over-representation of women in the service sector, both private and public, where part-time jobs are most prevalent. In addition, the unequal sharing of unpaid work between men and women is likely to play a role in women's voluntary part-time work. Parttime work generally carries a penalty in terms of pay, job security, training and promotion, although it varies across OECD countries. A penalty is found in most of these dimensions in Sweden, although it is relatively small by OECD standards (OECD, 2010). In terms of wages, the evidence is mixed. Bardasi and Gornic (2008) find that Sweden alone in a sample of six OECD countries displays no part-time wage penalty. The authors relate this result to the fact that working part-time is fairly common among Swedish females with young children, notably because parents of children below the age of eight are entitled to a $25 \%$ reduction in their working time (with a proportional pay reduction). In the other countries of their sample, part-time work is most prevalent in low-skilled and low-paid jobs, which partly explains the wage penalty. Wahlberg (2008), using quantile regressions, finds evidence of a part-time wage penalty in Sweden, which increases with the level of income and rises particularly sharply beyond the third quartile. At the median wage, the part-time penalty is less than $10 \%$ for women and slightly over $15 \%$ for men. In the highest decile, the penalty is close to $20 \%$ for women and $30 \%$ for men. 
Figure 9. Many women work part time, often involuntarily

A. Share of women working part-time, 2015

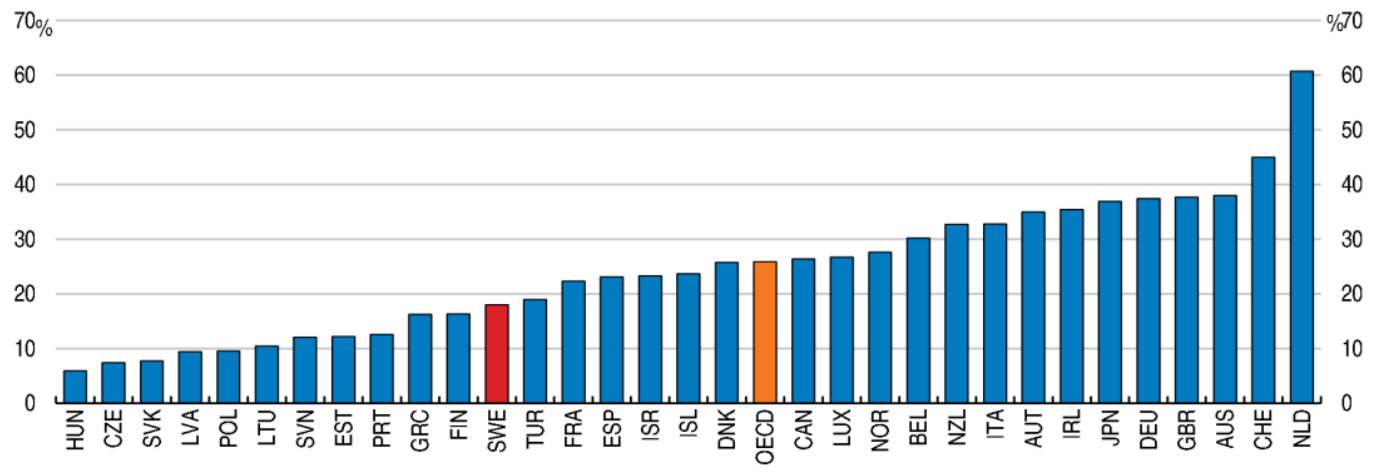

B. Share of women working involuntary part-time, 2015

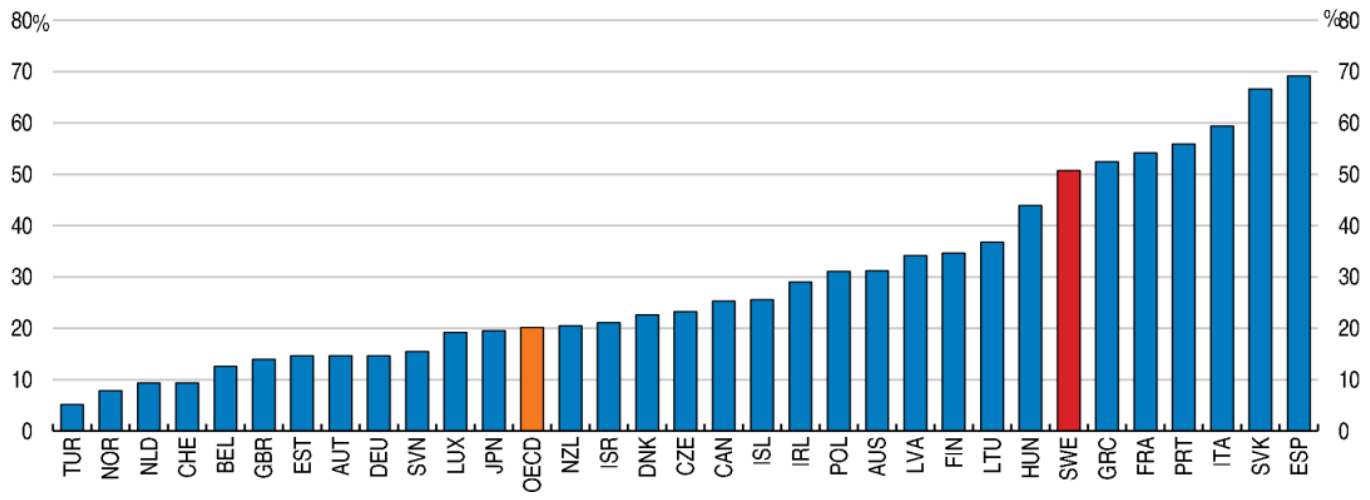

Source: OECD Labour Force Statistics.

\section{Women take on a larger share of unpaid work}

While Sweden is one of the best performers amongst the OECD, in relation to total time spent in unpaid work, and the gender gap is one of the smallest, women still spend more time in unpaid work than men (Figure 10). Sweden's relatively favourable result in this area is partly related to policies which favour female involvement in paid work and provide extensive public services, in particular child- and elderlycare. Moving further in that direction, the government has announced in its 2016 Spring fiscal policy bill that staffing in these services during unsocial working hours will be increased to enhance women's ability to work.

Figure 10 . Women spend more time than men in unpaid work ${ }^{1}$

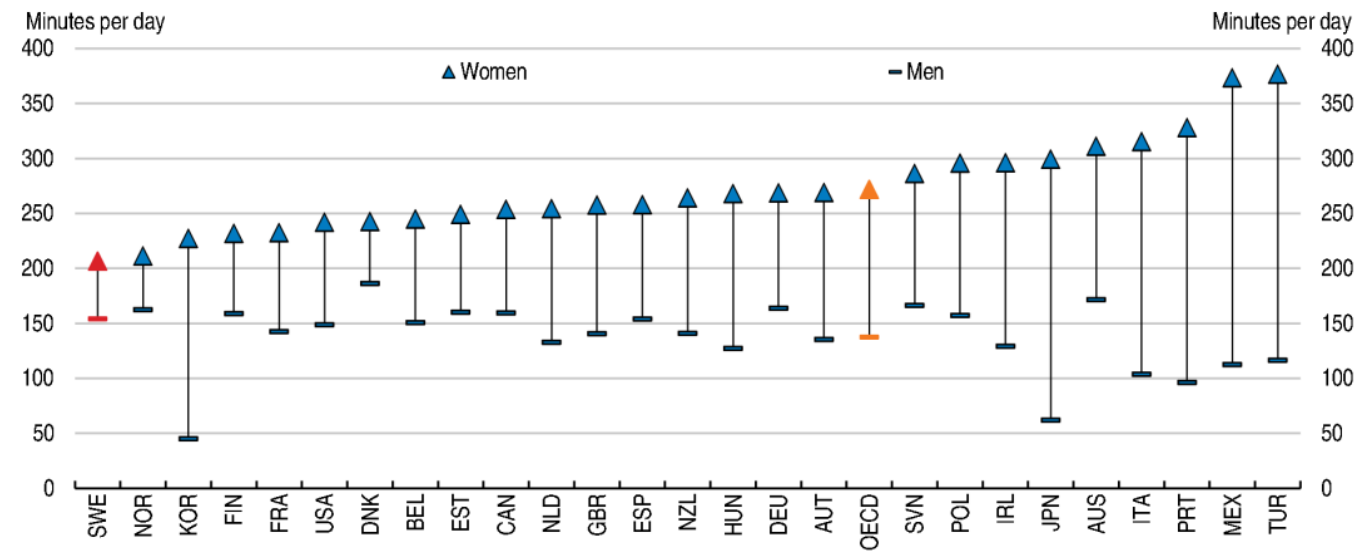

1. OECD Estimates based on Time Use Surveys, mostly from 2005 to 2010.

Source: OECD Gender Portal 2015. 


\section{Long parental leaves affect women's careers}

Sweden has among the most generous parental leave entitlements in the OECD, with a combination of relatively long duration and high replacement rate (Figure 11, Panel A). They cover job protection and income replacement. The current system, introduced in 1974, is credited with increasing female labour market participation, promoting male involvement in childcare, supporting fertility and enhancing children's well-being (Ferrarini and Duvander, 2010). The length of the leave, during which most parents receive $80 \%$ of previous earnings up to a relatively high cap, was progressively extended from six months initially to 16 months currently. A portion of the leave can be shared between parents, with the remainder reserved for mothers and fathers separately. This reserved part was introduced to encourage fathers to take parental leave. It was initially one month when it was introduced in 1995, extended to two months in 2002, and the current government raised it to three months in 2016, which is among the highest durations in the OECD (Panel B). In addition, countries with longer paid leave reserved for fathers have much lower replacement rates than Sweden (Adema et al., 2015). At the same time as the share reserved for each parent was extended, the gender equality bonus, a tax credit to parents sharing the leave equally introduced in 2008, was abolished, as it had proven ineffective (Duvander and Johansson, 2012). The municipal childcare allowance, introduced in 2008, was abolished in 2016. It provided extra childcare benefits to parents of one- and two-year olds who did not attend publicly subsidised day-care services, but had a low take up rate and was not available in all municipalities.

Figure 11. Parental leave is fairly generous
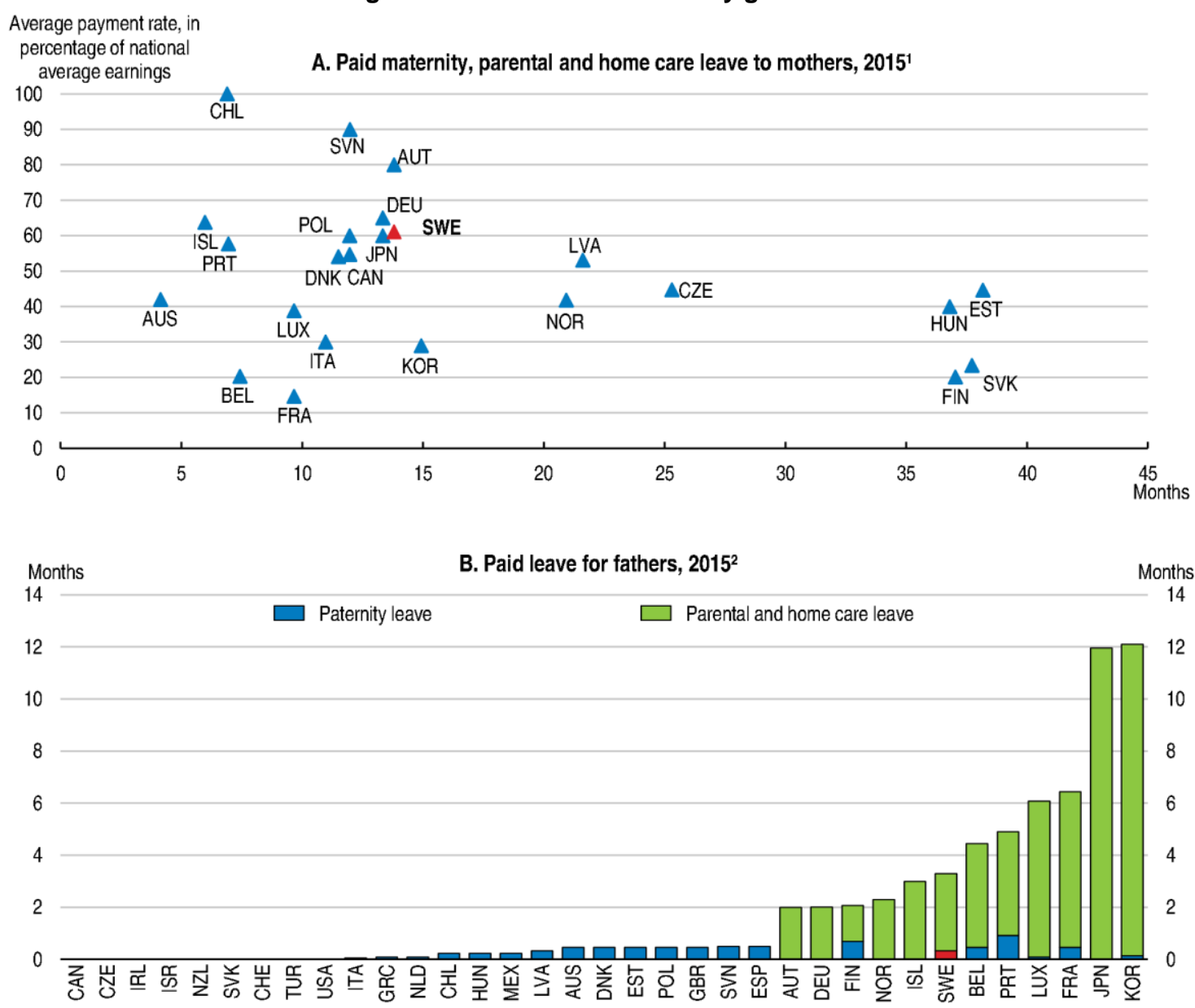

1. Countries with no paid home care leave are not shown.

2. 2016 for Sweden.

Source: OECD Family Database. 
Even though the majority of parental leave time is gender neutral and the share of parental leave used by men has increased steadily since the reserved quota for each parent was introduced two decades ago, $75 \%$ of parental leave is still taken by women. A more equal split of parental leave time would bring benefits in many areas. Parental leave schemes tend to push up female employment by providing an incentive to work before having children in order to accumulate rights to benefits, and by facilitating the return to work by offering job protection. However, long leave times have a detrimental impact on careers (Evertsson and Duvander, 2011; Thévenon and Solaz, 2013). Long periods out of work may erode human capital, through foregone experience, depreciation of skills during the leave and lower investment in careers, while possibly signalling weaker work commitment. Employers may also discriminate against childbearing-age women because of their higher probability of leave (Johansson, 2010). Hence, a more equal split of parental leave between parents would improve women's career prospects. Moreover, fathers taking parental leave tend to be more involved in childcare beyond the leave period. Better sharing of parental leave can lead to better long-term sharing of childcare and unpaid work, which in turn can enhance women's career prospects. However, evaluations of the effects on fathers' involvement in childcare and household work following the introduction of reserved shares in parental leave in Sweden are mixed. Ekberg et al. (2013) find no effect of the reform on the leave taken for care of sick children, which is correlated with household work. In contrast, Duvander and Johansson (2013) find a small but significant effect on the leave taken for care of sick children following the introduction of the first reserved month of parental leave. Finally, fathers' involvement in childcare improves children's cognitive development and well-being (Huerta et al., 2013).

Policies should encourage parents to split parental leave more equally by continuing to increase the share reserved for each parent. Although the free transfer of a large part of the parental leave between parents has advantages in terms of flexibility and accommodating individual preferences or constraints, it may lead to a sub-optimal allocation of leave between parents when choices are influenced by cultural attitudes. Research shows that in developed countries, there is an implicit bias - both from men and women - towards associating men with career and women with family (Duflo, 2012). Reflecting this bias, Swedish men tend to face a stronger penalty in terms of pay and career for taking long parental leaves than women do (Albrecht et al., 2015). This suggests that a long parental leave could be perceived more as a lack of commitment to the job when taken by a man, given prevailing social norms. Biased perceptions justify imposing, at least temporarily, limits on choices, such as a reserved share of parental leave for each parent. The government could progressively raise this share further. Iceland has the most egalitarian parental leave system in the OECD, with a third of the parental leave reserved for each parent and a third which can be shared between parents. However, the overall parental leave (9 months) is shorter than in Sweden.

Full rights to the parental leave minimum benefit are available for children up to the age of seven. They are seldom used by natives when children are over the age of three, but provide an incentive for female immigrants with children to stay at home, which exacerbates language learning disadvantages for their children, who do not participate in early childhood education and care (Swedish Government, 2016c).

\section{The gender pay gap persists, even though it is shrinking}

The Swedish gender pay gap is close to the OECD average (Figure 12). A large part of the gap results from differences in age, education, occupation, sector of employment and hours worked. Adjusting for these differences puts the gap, based on 2015 data, at 4.6\% (Swedish National Mediation Office, 2016). An alternative estimate from the Swedish National Mediation Office, which is based on regression analysis rather than the standard composition adjustment, shows a slightly smaller gender pay gap of $4.2 \%$. The adjusted gender pay gap is smaller in the public sector than in the private sector and is nearly closed in municipal governments. The large unadjusted wage gap in Swedish counties reflects the counties' responsibilities for health care, where men are over-represented among doctors, and women are overrepresented among nurses. When adjusted for this factor, the wage gap in counties is relatively small. In 
the private sector, the adjusted wage gap is more than twice as large for white collars as for blue collars (Table 1).

The unadjusted gender wage gap has been reduced by 3.8 percentage points between 2005 and 2015, while the adjusted gap has fallen by 2.2 percentage points. The narrowing of the wage gap in recent years can be decomposed into two effects: a reduction in gender segregation across occupations, accounting for between $60 \%$ and $70 \%$ of the reduction in the gender gap, and faster wage increases for women than for men, explaining the remaining 30 to $40 \%$ (Swedish National Mediation Office, 2015). Despite the decrease in the gender wage gap, two observations point to persisting gender inequality. First, wages tend to be lower in professions with a high proportion of women than in male-dominated occupations. This may result from lower productivity in some female-dominated sectors, notably in services, than in maledominated sectors. Hence, improving productivity in low-pay sectors would allow reducing the gender wage gap. Higher pay may also attract more men to these sectors, which would reduce job segregation. The role of low pay in that respect may be underestimated. For example, while the under-representation of men in pre-primary school teaching is generally attributed to the traditional association between caring and women, in a survey Norwegian men mentioned poor pay rather than fear of association with a caring role as a reason for not being attracted to the profession. Evidence from European countries and the United States suggests that lower wages in female-dominated professions could also result from undervaluation of the work done by women (Bettio and Verashchagina, 2009; Levanon et al., 2009). A recent study on Swedish young economics graduates suggests that women may also have lower wage expectations than men, which could negatively affect their ability to negotiate higher wages (Swedish National Mediation Office, 2016). However, a study from the Swedish Confederation of Professional Associations finds that women who have had individual wage negotiations have on average significantly higher wages than those who have not, while no such difference is found for men (Granqvist and Regnér, 2011). The gender wage gap tends to increase with the wage level. It is particularly high in the top percentiles of the distribution, pointing to the persistence of a glass ceiling for women (Albrecht et al., 2015).

\section{Figure 12. The gender wage gap is close to the OECD average}

2014 or latest year available

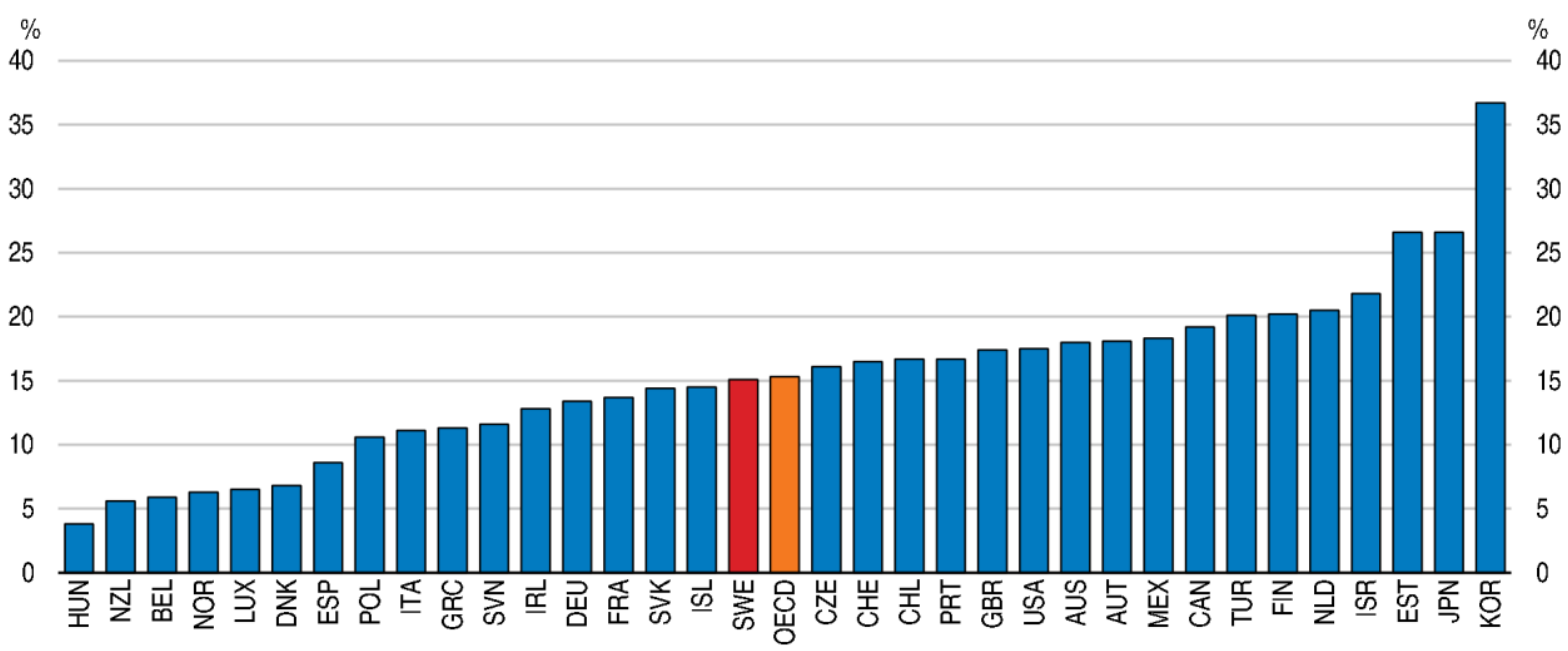

1. The gender wage gap is defined as the difference between male and female median wages divided by the male median wages. Source: OECD Employment Database. 
ECO/WKP(2017)27

Table 1. Gender wage gaps across sectors

Per cent, 2015

\begin{tabular}{lcc} 
& Unadjusted & Adjusted $^{\mathbf{1}}$ \\
\hline Total Economy & $\mathbf{1 2 . 5}$ & $\mathbf{4 . 6}$ \\
\hline Private sector & $\mathbf{1 1 . 9}$ & $\mathbf{5 . 7}$ \\
Blue collar & 10.3 & 3.1 \\
White collar & 18.3 & 7.7 \\
Public sector & $\mathbf{1 2 . 0}$ & $\mathbf{2 . 1}$ \\
Municipalities & 4.6 & 0.4 \\
Countries & 22.4 & 3.9 \\
State & 7.3 & 4.2 \\
\hline
\end{tabular}

1. Adjusted for differences in age, education, occupations, economic sectors and hours worked.

Source: Swedish National Mediation Office (Medlingsinstitutet) (2016).

\section{Despite success in political representation, the glass ceiling remains in many other areas}

Sweden has almost reached gender parity in political representation. Half of the government's ministers and $45 \%$ of Members of Parliament (MPs) are women. This achievement is the result of a long process to enhance the role of women in politics. In 1971, women accounted for only 14\% of MPs. From 1972 onwards, political parties progressively introduced voluntary quotas or targets for the share of women on candidates' lists and the number of women elected to the Swedish Parliament started rising steadily, their share exceeding $40 \%$ for the first time in the 1998 election. Other Nordic countries have also achieved comparable levels of female representation in parliament; Norway and Iceland also have voluntary party quotas, but this is not the case in Denmark and Finland (Freidenvall and Dahlerup, 2013).

Gender equality in the business sector has improved far less rapidly than in the political sphere. The fairly low share of women among top managers and company board members suggests that there is a glass ceiling for women. The women's share of board members of the largest listed companies is below one third, even though it is one of the highest among OECD countries (Figure 13). The government intended to submit legislation to Parliament requiring that at least $40 \%$ of listed company board members be women in 2017. In case of non-compliance, firms could have been fined up to five million krona (about USD 600 000). But the project was abandoned, as it appeared that it was unlikely to gather the necessary support in Parliament. The legislation echoes similar legislation introduced in Norway in 2003 (Box 3). Despite the economic and societal benefits of improved gender equality, quotas have some drawbacks. Ideally, firms should be allowed to select freely the best candidates for a position solely on the basis of their competencies. It is sometimes argued that targets are better than mandatory quotas, as they incentivise firms to move towards gender equality, while providing the necessary flexibility to avoid sub-optimal decisions in terms of human resource management (OECD, 2016c). Quotas on company boards may also mask ongoing power imbalances between genders, as women continue to be under-represented in executive positions. Nevertheless, the persistence of cultural influences and implicit perception bias in candidates' selection provides support for the imposition of gender quotas, at least temporarily (Duflo, 2012). 
Figure 13. Less than one third of company board members are women Women's share of seats on boards of the largest publicly listed companies, 2015

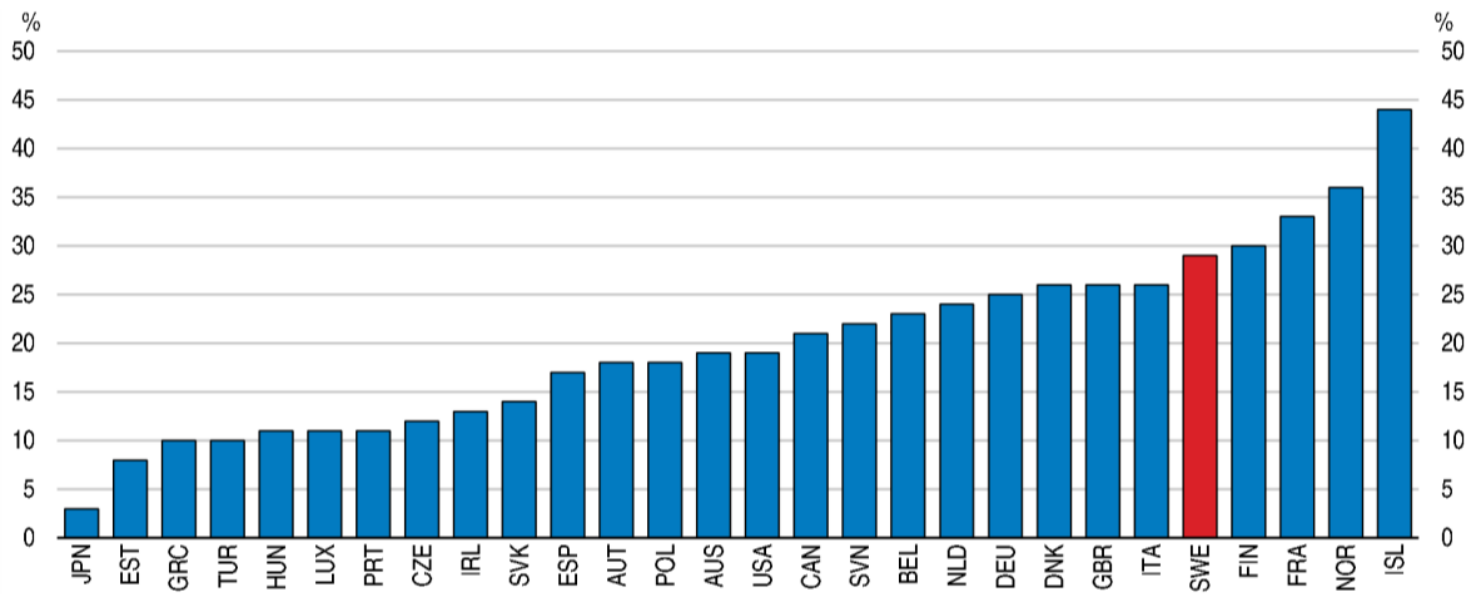

Source: OECD Employment Database.

Women are also under-represented in senior management, even though with a women's share of about $30 \%$, Sweden is close to the OECD average (Figure 14) and the percentage of managers and professionals among female secondary earners is the second highest in the EU, reflecting Swedish women's high level of education (Rastrigina and Verashchagina, 2015). The under-representation of women in senior management warrants special attention not only from an equity point of view, but also given evidence that female executives can have more of an impact on firm performance than female board members (Noland et al., 2016). Achieving parity in management positions, especially at the most senior levels, may be more challenging and take more time than for company board members, as many managers are promoted internally and maintaining a balance between internal and external promotions is often necessary to preserve experience and staff motivation.

\section{Box 3. Gender quotas on company boards in Norway}

In December 2003, the Norwegian Parliament amended the Company Act, adding a legal requirement for at least $40 \%$ representation of each gender on company boards, making Norway the first OECD country to implement quota legislation beyond the public sector. The legislation applies to all publicly-owned companies (state-owned, municipal, inter-municipal) and to public limited companies, which were granted a two-year adjustment period. Despite a sharp increase, the proportion of women on public limited company boards only reached $18 \%$ in 2005 . Therefore, sanctions were introduced, which could entail the forced dissolution of a company which failed to comply. By 2008 , the quota was reached (Teigen, 2015).

The quota law was the subject of an intense public debate, and met strong opposition from key players in the Norwegian business sector. The main arguments against the law were that it would lead to the replacement of skilled and experienced men by less skilled and experienced women, and that it would hinder the owners' democratic right to recruit the best candidates (Storvik and Teigen, 2010). Several databases have been developed in order to facilitate the identification of skilled women to fill board positions, often along with specific programmes to upskill women on board and management topics.

The quotas have achieved their direct goal, as the share of women has increased from almost nothing to about $40 \%$ on the boards of companies subject to the regulation. However, the full economic consequences of the law are still unclear. Concerns about difficulties to find skilled women have been proven wrong. The average qualification of women appointed to the boards of public limited companies improved after the reform, and the gap in qualification between men and women narrowed (Bertrand et al., 2014). There is little evidence, however, that this has led the largest private limited companies, which are not bound by the quota, to recruit more women on their boards. Furthermore, having more women on the boards has not led to an increase in the share of women in senior management positions, with $90 \%$ of companies' senior management teams being male-dominated (defined as more than $60 \%$ of men) and $92 \%$ of CEOs being men (Halrynjo et al., 2015).

The quota law has attracted considerable international interest, and countries like Belgium, France, Germany, Iceland, Italy and Spain have started to implement similar regulations to move towards more gender equality on company boards, though sanctions in case of non-compliance appear to be less severe than in Norway (Teigen, 2015). 
Figure 14. Women are under-represented in management ${ }^{1}$ Latest year available

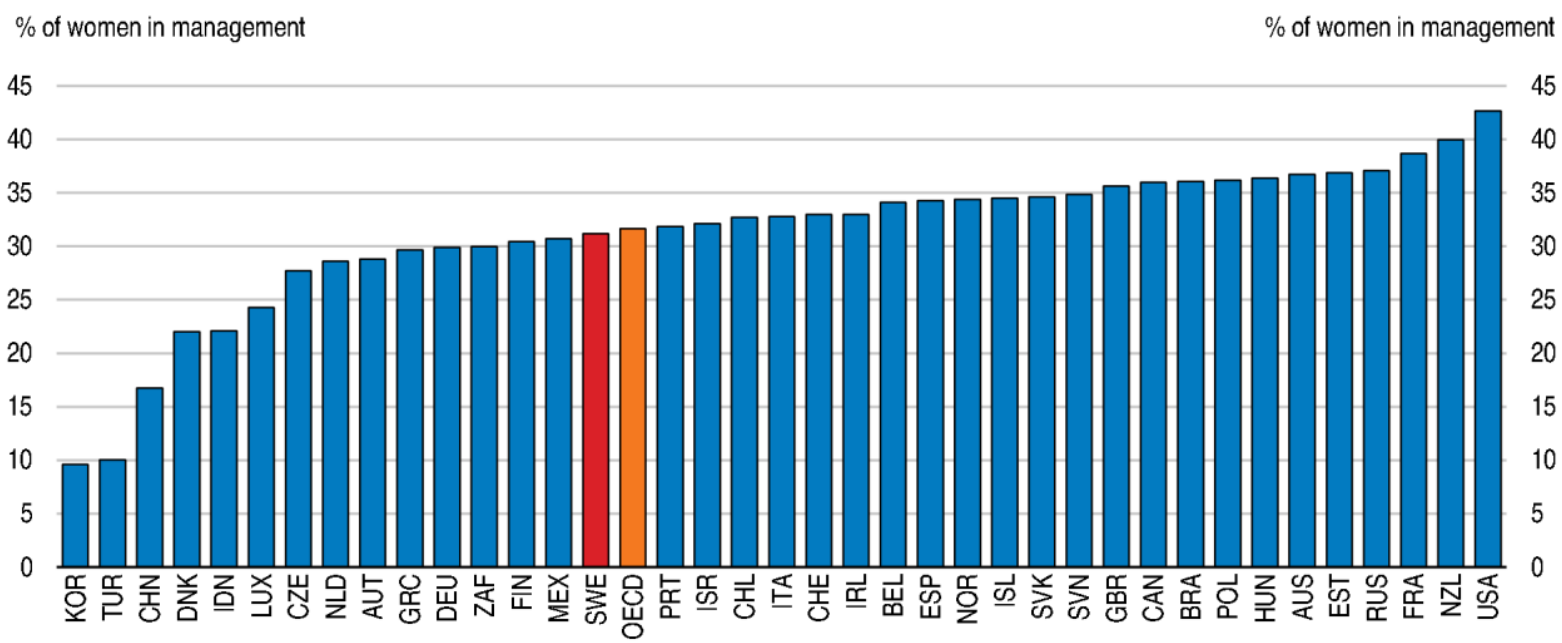

1. Covers Category 1 of the International Standard Classification of Occupations (ISCO), which includes legislators, senior officials and managers.

Source: OECD Employment Database; ILO, Key Indicators of Labour Market (KILM) database.

\section{Segregation and stereotypes in education and the labour market need to be fought}

Women are under-represented in many well-paid and influential professions. Women account for less than $30 \%$ of information and communication employees and only slightly over $40 \%$ of professional, scientific and technical workers. Conversely, they account for $80 \%$ of health and social workers and more than $70 \%$ of education employees. While this distribution is highly skewed according to gender, it is relatively similar to that of other Nordic countries (Figure 15).

\section{Figure 15. Gender segregation across occupations is high}

Share of women by main activities, 2015

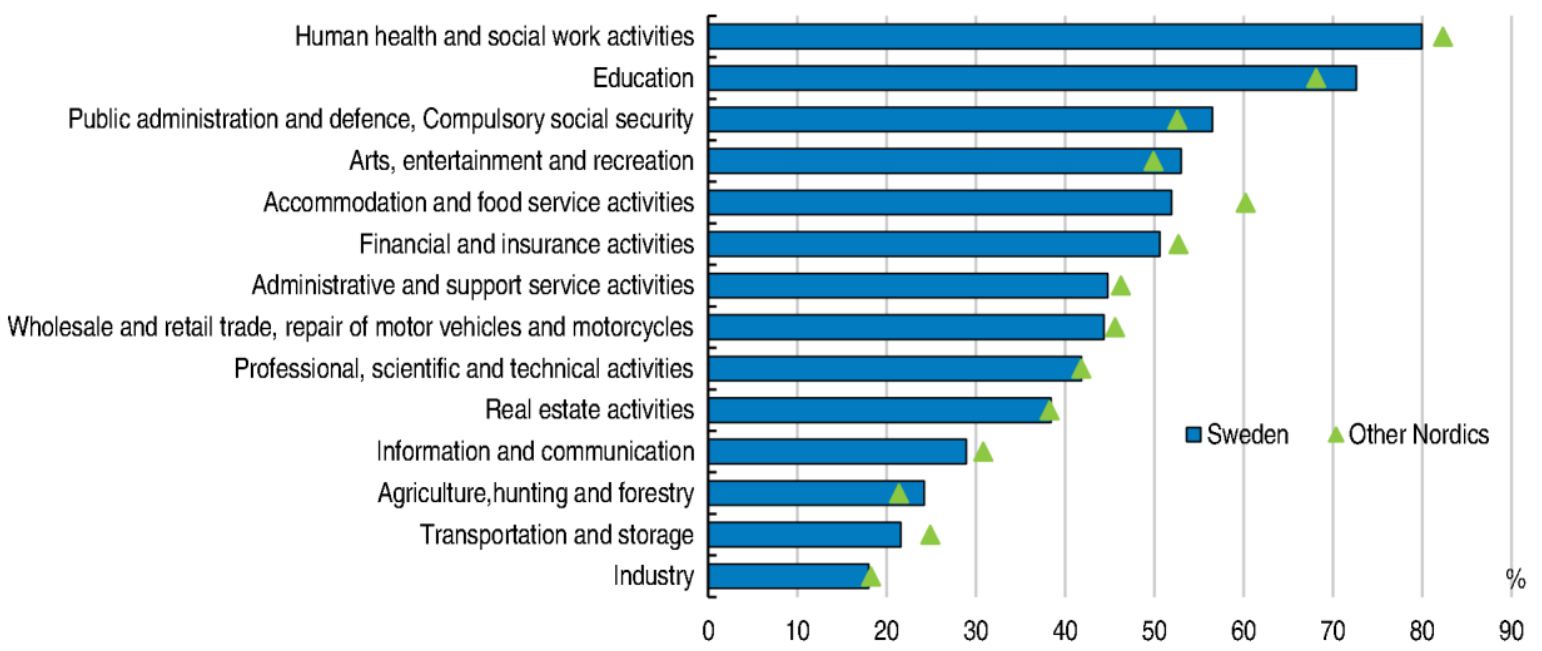

Source: OECD Labour Force Statistics.

The distribution of genders across professions matches education choices. Women account for only about a quarter of engineering and computing graduates, but for more than $80 \%$ of education and health and welfare graduates (Figure 16). Education choices are determined by preferences but are also influenced 
by social norms. The internalisation of social norms is partly unconscious, but may also reflect perceived hurdles in accessing a profession. For example, girls may hesitate to study engineering if they think that they are at a disadvantage for entry and progression in science and technology-related professions. This obstacle can be overcome by closer cooperation between schools and trade associations, civil society groups and the business community (OECD, 2015b). As companies increasingly realise the benefits of gender diversity, opportunities for such cooperation increase. Sweden, like several other European countries, has developed vocational training programmes specifically designed to lower employment segregation. Such programmes generally target females, but attention should also be paid to enhancing opportunities for boys to enter traditionally female-dominated professions (Bettio and Verashchagina, 2009).

As promoting gender equality among adults has often had limited effects, the focus is increasingly on combatting gender stereotypes in schools and pre-schools. Sweden, like other Nordic countries, Germany and the Netherlands, has taken initiatives to address gender stereotypes from an early age through educational programmes aimed at freeing children from gender roles to widen their choices (ILO, 2016). Since 1998, Swedish legislation states that all schools must counteract gender stereotypes. This starts in pre-schools where "girls and boys (...) should have the same opportunities to develop and explore their abilities and interests without having limitations imposed by stereotyped gender roles" (Swedish National Agency for Education, 2010). Gender pedagogy projects have been implemented in many Swedish preschools. They are often based on "compensatory pedagogy", where children are encouraged to develop their traditionally weakest skills, for example verbal communication and care for boys and autonomy and assertiveness for girls. Gender equality projects seem to have had some positive effects and to have raised awareness about gender equality and stereotypes (Bayne, 2009).

\section{Figure 16. Education choices vary widely across genders}

Share of women graduating by field of education, $2014^{1}$

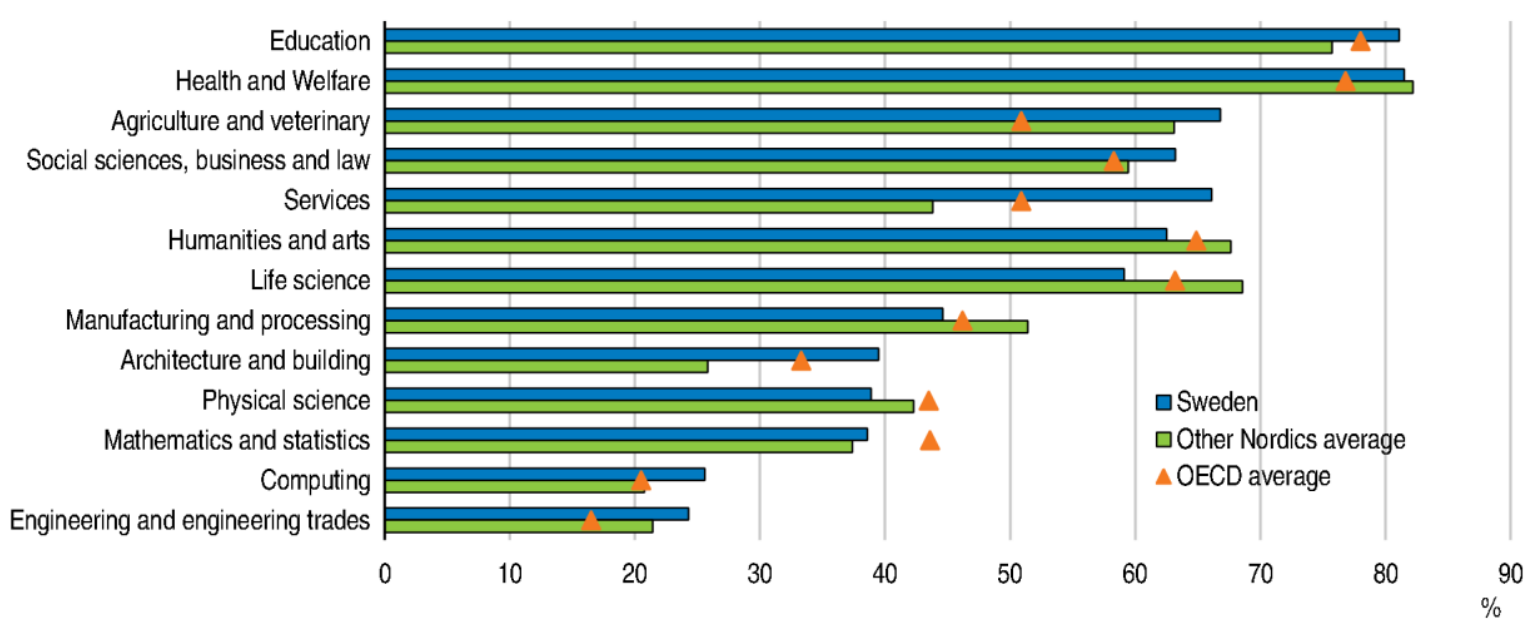

1. Level of education: total tertiary education (ISCED2011 levels 5 to 8). 2013 for the OECD average and for the fields below life science.

Source: OECD Education at a Glance.

\section{Female entrepreneurship should be promoted further}

The share of women among entrepreneurs is fairly small in most OECD countries, as women tend to be more risk-averse and face more obstacles to start or grow a business than men. However, over a third of sole proprietor enterprises are owned by women, which is one of the highest shares among OECD countries for which data are available, with only France, Korea and Mexico having a higher share of women owners (Figure 17). Furthermore, women entrepreneurship is growing fast in Sweden. Between 2006 and 2012, the number of businesses owned by women increased by $34 \%$, accounting for an increase 
of $62 \%$ in net sales, compared to $19 \%$ and $17 \%$ for male-owned businesses. This contrasts with little evidence of progress in women entrepreneurship in most OECD countries over the past decade (Piacentini, 2013). Nevertheless, if current trends prevailed, parity in entrepreneurship would be reached only around 2050 (Swedish Agency for Economic and Regional Growth, 2015a).

Enterprises run by different genders in Sweden mainly differ according to their sector of activity. Nine out of ten female-owned enterprises are in services, compared to only seven out of ten for men. Manufacturing and construction are still mostly dominated by male owners. Female-run businesses make up the majority of companies in arts, entertainment and recreation; health and social services; and other personal services (e.g. spas, haircare and laundry). Many companies run by women are also found in professional, scientific and technical activities, as well as wholesale and retail trade. Female-owned companies differ from male-owned companies across other dimensions as well. In particular, women's companies are often smaller, less internationalised and cooperate less with other companies. Women entrepreneurs are on average younger and have a higher level of education than their male counterparts, like in other OECD countries (Piacentini, 2013). Nearly eight out of ten women wish to grow their business, a somewhat higher proportion than for men. The main obstacle to growth, both for men and women, is a lack of personal time. Difficulty to obtain loans is a constraint for less than $10 \%$ of women's businesses, a slightly smaller proportion than for men (Swedish Agency for Economic and Regional Growth, 2012).

Recognising that women were facing specific obstacles to creating and growing a business, the government mandated the Swedish Agency for Economic and Regional Growth to design and implement a programme to promote female entrepreneurship over 2007-14. Business development programmes, which included advisory services, coaching, mentoring, networking and training, were developed and entrepreneurship projects were set up at universities and other higher-education institutions. Efforts were made to spread Golden Rules of Leadership, stressing the importance of mentoring, networking and role models. Ambassadors for female entrepreneurship were appointed and shared their entrepreneurial experience in various fora and the introduction of female entrepreneur awards served to create role models. Many women were involved in the activities of the programme and satisfaction was high (Swedish Agency for Economic and Regional Growth, 2015a).

Figure 17. Only a third of sole-proprietor enterprises are owned by women

Latest year available

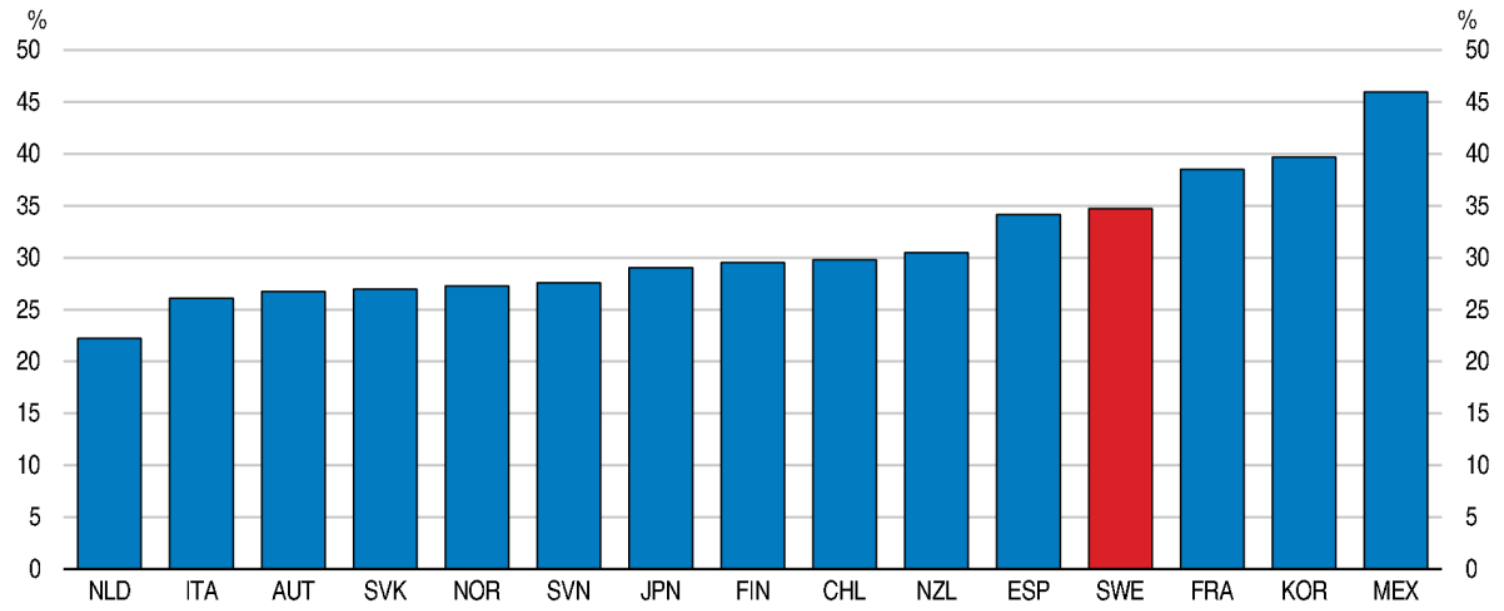

Source: OECD Entrepreneurship Database.

The next step was to develop a national strategy for business promotion on equal terms for the period 2015-20 (Swedish Agency for Economic and Regional Growth, 2015b). "On equal terms" does not only refer to gender, but also to age and ethnic background, as young and foreign-born people tend to face similar disadvantages as women. Business promotion has traditionally focussed on sectors like industry 


\section{ECO/WKP(2017)27}

and manufacturing, where women are under-represented. Expanding business support and financing in the service sector will rebalance benefits towards women, as well as strengthen growth, competitiveness and innovation across the economy. Leadership - especially awareness and communication about equality and diversity - and governance - in particular setting targets for allocating funding and monitoring progress in equality - have a key role to play in achieving the goal of creating a level playing field for entrepreneurs. Developing further data disaggregated by gender, age and foreign background and their analysis will be essential to evaluate the strategy.

\section{Box 4. Recommendations on fighting gender inequality}

\section{Key recommendations}

Encourage parents to split parental leave more equally by continuing to increase the share reserved for each parent.

Enhance active labour market policy for foreign-born women when the Introduction programme ends, to prevent them from drifting away from the labour market.

\section{Further recommendations}

Expand data coverage and analysis in the government budget annex on gender equality. Consider developing intermediate targets related to the broad gender equality objectives, to facilitate the monitoring and evaluation of policies.

Continue to develop methods to fight stereotypes in education. Address gender-specific weaknesses in education, whether faced by girls or boys.

Further promote female entrepreneurship through business promotion programmes creating a level playing field irrespective of gender, age or ethnic background. Develop data and analytical tools to evaluate these programmes. 


\section{REFERENCES}

Adalet McGowan, M. (2013), "Housing, financial and capital taxation policies to ensure robust growth in Sweden", OECD Economics Department Working Papers, No. 1024, OECD Publishing. http://dx.doi.org/10.1787/5k4c0vtc1kkk-en

Adalet McGowan, M. and D. Andrews (2015a), "Labour market mismatch and labour productivity: evidence from PIAAC data", OECD Economics Department Working Papers, No. 1209, OECD Publishing. http://dx.doi.org/10.1787/5js1pzx1r2kb-en

Adalet McGowan, M. and D. Andrews (2015b), "Skill mismatch and public policy in OECD countries", OECD Economics Department Working Papers, No. 1210, OECD Publishing. http://dx.doi.org/10.1787/5js1pzw9lnwk-en

Adema, W., C. Clarke and V. Frey (2015), "Paid parental leave: lessons from OECD countries and selected U.S. states", OECD Social, Employment and Migration Working Papers, No. 172, OECD Publishing. http://dx.doi.org/10.1787/5jrqgvqqb4vb-en

Albrecht, J., P. Skogman Thoursie and S. Vroman (2015), "Parental leave and the glass ceiling in Sweden", IFAU (Institute for Evaluation of Labour Market and Education Policy) Working Paper Series, 2015:4, Uppsala.

Bardasi, E. and J.C. Gornick (2008), "Working for less? Women's part-time wage penalties across countries", Feminist Economics, Vol. 14/1.

Bayne, E. (2009), “Gender pedagogy in Swedish pre-schools: an overview”, Gender Issues, Vol. 26/2.

Bertrand, M. et al. (2014), "Breaking the glass ceiling? The effect of board quotas on female labor market outcomes in Norway", NBER Working Papers, No. 20256.

Bettio, F. and A. Verashchagina (2009), Gender Segregation in the Labour Market, Root Causes, Implications and Policy Responses in the EU, European Commission, Directorate-General for Employment, Social Affairs and Equal Opportunities.

Boulhol, H. and L. Turner (2009), "Employment-productivity trade-off and labour composition", OECD Economics Department Working Papers, No. 698, OECD Publishing. http://dx.doi.org/10.1787/224146182015

Catalyst (2011), "The bottom line: corporate performance and women's representation on boards (20042008)", Catalyst, New York.

Croson, R. and U. Gneezy (2009), "Gender differences in preferences", Journal of Economic Literature, Vol. 47/2.

Curtis, M., C. Schmid and M. Struber (2012), "Gender diversity and corporate performance”, Credit Suisse Research Institute, Zurich.

Del Prete, S. and M.L. Stefani (2015), "Women as 'gold dust': gender diversity in top boards and the performance of Italian banks", Bank of Italy Working Papers, No. 1014. 
Duflo, E. (2012), "Women empowerment and economic development", Journal of Economic Literature, Vol. 50/4.

Duvander, A.-Z. and M. Johansson (2012), "What are the effects of reforms promoting fathers' parental leave use?”, Journal of European Social Policy, Vol. 22/3.

Duvander and Johansson (2013), "Effekter på jämställdhet av reformer i föräldrapenningen” (Effects on gender equality of reforms in the parental leave insurance), Swedish Social Insurance Inspectorate Report 2013:17, Stockholm.

Ekberg, J., R. Eriksson and G. Friebel (2013), "Parental leave - A Policy Evaluation of the Swedish "Daddy-Month" Reform", Journal of Public Economics, Vol 97.

European Institute for Gender Equality (2015), Gender Equality Index 2015 - Measuring Gender Equality in the European Union 2005-2012, Vilnius.

Evertsson, M. and A.-Z. Duvander (2011), "Parental leave - possibility or trap? Does family leave length affect Swedish women's labour market opportunities?”, European Sociological Review, No. 4.

Ferrarini, T. and A.-Z. Duvander (2010), "Earner-carer model at the crossroads: reforms and outcomes of Sweden's family policy in comparative perspective", International Journal of Health Services, Vol. 40/3.

Freidenvall, L. and D. Dahlerup (2013), Electoral Gender Quota Systems and their Implementation in Europe, Update 2013, European Parliament, European Union, Brussels.

Galinsky, A. et al. (2015), "Maximizing the gains and minimizing the pains of diversity: a policy perspective", Perspectives on Psychological Science, Vol. 10/6.

Gonzales, C. et al. (2015), "Catalyst for change: empowering women and tackling income inequality", IMF Staff Discussion Note, SDN/15/20, International Monetary Fund, Washington.

Granqvist, L and H. Regnér (2011), "Kvinnor och män i en individualiserad lönebildning”, Swedish Confederation of Professional Associations (SACO), Stockholm.

Gunnarsson, Å (2016), “Introducing independent income taxation in Sweden in 1971”, FairTax Working Paper Series, No. 2, Umeå.

Halrynjo, S., M. Teigen and M. Nadim (2015), "Women and men in senior management. Ripple effects of laws requiring gender balance on company boards", in Teigen, M. (ed) (2015), Gender balance on company boards, a summary from a research project about the impact of the Norwegian gender quota legislation, Institute for Social Research, Oslo.

Huerta, M. et al. (2013), “Fathers' leave, fathers' involvement and child development: are they related? Evidence from four OECD countries", OECD Social, Employment and Migration Working Papers, No. 140, OECD Publishing. http://dx.doi.org/10.1787/5k4dlw9w6czq-en

Hunt, V., D. Layton and S. Prince (2015), Diversity Matters, McKinsey \& Company.

ILO (2016), Women at Work: Trends 2016, International Labour Office, Geneva. 
Johansson, E.-A. (2010), "The effect of own and spousal parental leave on earnings", Institute for Labour Market Policy Evaluation (IFAU) Working Papers, No. 2010:4, IFAU, Uppsala.

Levanon, A., P. England and P. Allison (2009), "Occupational feminization and pay: assessing causal dynamics using 1950-2000 U.S. Census data”, Social Forces, Vol. 88/2.

MHSA (2015), Policy Objectives and a New Government Agency - Effective Governance of Swedish Gender Equality Policy (SOU 2015:86), Summary of the Report by the Gender Equality Inquiry, Ministry of Health and Social Affairs, Stockholm.

Noland, M., T. Moran and B. Kotschwar (2016), "Is gender diversity profitable? Evidence from a global survey", Peterson Institute for International Economics Working Paper Series, No. 16-3, Washington DC.

OECD (2010), OECD Employment Outlook 2010: Moving beyond the Jobs Crisis, OECD Publishing.

OECD (2012), Closing the Gender Gap: Act Now, OECD Publishing. http://dx.doi.org/10.1787/9789264179370-en

OECD (2013), How's Life? 2013: Measuring Well-being, OECD Publishing. http://dx.doi.org/10.1787/9789264201392-en

OECD (2015a), Entrepreneurship at a Glance 2015, OECD Publishing. http://dx.doi.org/10.1787/entrepreneur_aag-2015-en

OECD (2015b), The ABC of Gender Equality in Education: Aptitude, Behaviour, Confidence, PISA, OECD Publishing. http://dx.doi.org/10.1787/9789264229945-en

OECD (2016a), Education at a Glance 2016: OECD Indicators, OECD Publishing, Paris. http://dx.doi.org/10.187/eag-2016-en

OECD (2016b), Working Together: Skills and Labour Market Integration of Immigrants and their Children in Sweden, OECD Publishing. http://dx.doi.org/10.1787/9789264257382-en

OECD (2016c), “Improving Women's access to leadership: what works?", Conference on improving women's access to leadership, 8 March, OECD, Paris, Background report.

Piacentini, M. (2013), "Women entrepreneurs in the OECD: key evidence and policy challenges", OECD Social, Employment and Migration Working Papers, No. 147, OECD Publishing. http://dx.doi.org/10.1787/5k43bvtkmb8v-en

Quinn, S. (2016), "Europe: A survey of gender budgeting efforts", IMF Working Papers, No. 16/155, International Monetary Fund, Washington.

Rastrigina, O. and A. Verashchagina (2015), "Secondary earners and fiscal policies in Europe”, European Commission, Brussels.

Salvi del Pero, A. and A. Bytchkova (2013), "A bird's eye view of gender differences in education in OECD countries", OECD Social, Employment and Migration Working Papers, No. 149, OECD Publishing. http://dx.doi.org/10.1787/5k40k706tmtb-en 
Storvik, A. and M. Teigen (2010), "Women on board: the Norwegian experience", International Policy Analysis, Fredrich Ebert Stiftung, Berlin.

Swedish Agency for Economic and Regional Growth (2012), Women's and Men's Enterprise in Sweden, The Situation and Conditions of Enterprises, Facts and statistics, Tillväxtverket, Stockholm.

Swedish Agency for Economic and Regional Growth (2015a), 8 Years of Promoting Women's Entrepreneurship in Sweden, Tillväxtverket, Stockholm.

Swedish Agency for Economic and Regional Growth (2015b), Open Up, A National Strategy for Business Promotion on Equal Terms 2015-2020, Tillväxtverket, Stockholm.

Swedish Fiscal Policy Council (2016), Swedish Fiscal Policy, Stockholm.

Swedish Government (2016a), "Långsiktigt Reformprogram för Minskad Segregation år 2017-2025" (Long-term Reform Programme to Reduce Segregation 2017-2025), Promemoria, Regeringskansliet, Stockholm (in Swedish).

Swedish Government (2016b), From the Spring Fiscal Policy Bill 2016: Guidelines for economic and budget policy, Stockholm.

Swedish Government (2016c), Begränsningar i föräldrapenningen för föräldrar som kommer till Sverige med barn, SOU 2016:73, Stockholm.

Swedish National Agency for Education (2010), Curriculum for the Preschool Lpfö 98, Revised 2010, Skolverket, Stockholm.

Swedish National Mediation Office (Medlingsinstitutet) (2015), Löneskillnaden mellan kvinnor och män 2014, Vad säger den officiella lönestatistiken? (The pay gap between women and men in 2014, what do the official wage statistics say?), Medlingsinstitutet, Stockholm (in Swedish).

Swedish National Mediation Office (Medlingsinstitutet) (2016), Löneskillnaden mellan kvinnor och män 2015, Vad säger den officiella lönestatistiken? (The pay gap between women and men in 2015, what do the official wage statistics say?), Medlingsinstitutet, Stockholm (in Swedish).

Teigen, M. (2015), "Gender balance on the boards and management of the Norwegian business sector" in Teigen, M. (ed) (2015), Gender Balance on Company Boards, A Summary from a Research Project About the Impact of the Norwegian Gender Quota Legislation, Institute for Social Research, Oslo.

Thévenon, O. and A. Salvi Del Pero (2015), "Gender equality (f)or economic growth? Effects of reducing the gender gap in education on economic growth in OECD countries", Annals of Economics and Statistics, No. 117/118.

Thévenon, O. and A. Solaz (2013), "Labour market effects of parental leave policies in OECD countries", OECD Social, Employment and Migration Working Papers, No. 141, OECD Publishing. http://dx.doi.org/10.1787/5k8xb6hw1wjf-en

United Nations Development Programme (2015), Human Development Report 2015, Work for Human Development, UNDP, New York.

Wahlberg, R. (2008), "Part-time penalty in Sweden: evidence from quantile regression", University of Gothenburg Working Papers in Economics, No. 315. 
Woolley, A. et al. (2010), "Evidence for a collective intelligence factor in the performance of human groups", Science, Vol. 330/6004.

World Economic Forum (2016), The Global Gender Gap Report 2016, Geneva. 